\title{
OLHARES DOCENTES: UM ESTUDO SOBRE A INCLUSÃO DAS CRIANÇAS COM NECESSIDADES EDUCACIONAIS ESPECÍFICAS NO CONTEXTO ESCOLAR $^{1}$
}

\author{
TEACHERS' OUTLOOKS: A STUDY ON THE INCLUSION OF CHILDREN WITH \\ SPECIFIC EDUCATIONAL NEEDS IN THE SCHOOL SETTING
}

\author{
Euzilene Ferreira de Rezende ${ }^{2}$
}

RESUMO: O presente artigo tem como propósito apresentar os resultados da pesquisa ${ }^{3}$ que investigou a inclusão de alunos com necessidades educacionais específicas na Educação Infantil, do município de Trindade/GO, a partir da percepção docente. O objetivo geral do estudo foi evidenciar os aspectos da operacionalização da inclusão, na educação infantil do referido município, sob a ótica do professor e, dentre os objetivos específicos, identificar se o sistema educacional incentiva a participação docente em cursos de formação continuada. Trata-se de uma pesquisa de campo, de natureza qualiquantitativa. A amostra foi formada por 25 professoras que atendem na educação infantil da referida rede de ensino. Para coleta de dados foram utilizadas as seguintes técnicas: questionário semiestruturado e análise documental. $\mathrm{O}$ tratamento dos dados deu-se à luz da ótica da análise de conteúdo. A análise da pesquisa revelou que o processo inclusivo acontece a partir: de instituições favoráveis à inclusão, contando com diretores, coordenadores, colaboradores e docentes totalmente abertos a esta questão e cientes da importância da presença das crianças com NEE no contexto regular de ensino; da atuação conjunta de profissionais de apoio (pedagógico e higienizador), professores regentes e de AEE, bem como do suporte da equipe multiprofissional da Secretaria Municipal de Educação (assistente social, fonoaudióloga, psicóloga e psicopedagoga) e das famílias; do trabalho desenvolvido pelas docentes que é marcado pelo sentimento de pertença, não somente em relação ao acolhimento, mas ao planejarem as atividades propostas em sala de aula, promovendo a interação e considerando o que é particular a cada criança, mesmo sem condições favoráveis tal fim. Revelou também que o sistema educacional incentiva a capacitação e que a formação continuada das interlocutoras-professoras participantes constitui um diferencial para atuar no processo inclusivo, por possibilitar melhores condições para promover a escolarização das crianças atendidas. Todavia, a capacitação contínua, por si só, não garante a efetivação da inclusão escolar no município estudado. São necessários, segundo os dados analisados, elementos básicos para a inclusão: políticas públicas efetivas, materiais/recursos pedagógicos, infraestrutura física com acessibilidade, qualificação da equipe de apoio (contratos

\footnotetext{
A realização deste estudo só foi possível graças as riquíssimas contribuições da Profa. Dra. Selma Regina Gomes e das colaborações: da Secretaria Municipal de Educação de Trindade/GO; dos Gestores das instituições escolares e principalmente, das Docentes da Educação Infantil, que tão atenciosamente se disponibilizaram à participação, tamanha vontade delas em oferecer às crianças uma educação de qualidade. Recebam todos, os meus sinceros agradecimentos!

${ }^{2}$ Mestre em Educação-FacMais - Faculdade de Inhumas/GO - E-mail: euzilenerezende@hotmail.com

${ }^{3}$ Refere-se aos estudos do mestrado. O presente artigo contempla partes da dissertação apresentada ao Programa de PósGraduação em Educação - Faculdade de Inhumas/GO.
} 
temporários), projetos que envolvam a família e outros. Por fim, o estudo revelou que muito ainda precisa ser feito para que a educação infantil inclusiva se legitime no município de Trindade/GO.

Palavras-chave: Inclusão Escolar. Educação Infantil. Formação de Professores. Trindade/GO.

ABSTRACT: The purpose of this article is to showcase the results of a research that investigated the inclusion of students with specific educational needs in Kindergarten, in the city of Trindade/GO, based on the teachers' perception. The main goal of the study is to highlight aspects of the operationalization of inclusion, in early childhood education in that municipality, from the perspective of the teacher and, among the specific objectives, to identify whether the educational system encourages teacher participation in continuing education courses. This study is field research of both quantitative and qualitative nature. The sample consisted of 25 teachers who work in early childhood education in the previously mentioned school system. The techniques used for data collection were: semistructured questionnaire and document analysis. Data treatment was carried out from the perspective of content analysis. The research analysis revealed that the inclusive process stems from: institutions in favour of inclusion, where headteachers, coordinators, collaborators and teachers are open to this issue and aware of the importance of the presence of children with SEN in the regular context of education; the joint action of support professionals (both on pedagogical and school maintenance areas), regents and specialized educational teachers, as well as the support of the multidisciplinary team from the Municipal Department of Education (social assistants, speech therapists, psychologists and educational psychologist) and families; the work carried out by the teachers, which is etched by the feeling of belonging, not only in the welcoming but when planning the activities for the classroom, as to promote interaction aware of what is unique to each child, even without favourable conditions for this intent. It also revealed that the educational system encourages training and that the continuing education of the participating interlocutors-teachers is an advantage when working in the inclusive process, as it provides better conditions to promote schooling for the children. However, continuous training by itself does not guarantee the effectiveness of school inclusion in the municipality. According to the analysed data, there are essential elements necessary for inclusion: effective public policies, teaching materials/resources, accessible infrastructure, a qualified support team (temporary contracts), projects that engage the family and others. Finally, the study reveals that much still needs to be done for an inclusive early childhood education to be guaranteed in the city of Trindade/GO.

Keywords: School Inclusion. Child Education. Teacher Training. Trindade/GO.

\section{INTRODUÇÃO}


O foco de análise desta pesquisa é a educação inclusiva na educação infantil. Isto é, busca-se elucidar como têm sido incluídas as crianças com necessidades educacionais específicas ${ }^{4}$ (NEE) na primeira infância escolar. Momento particular em que a criança "[...] precisa de situações estimuladoras para que cresça e avance em todos os aspectos de sua personalidade, a partir de uma construção ao mesmo tempo social e pessoal [...]" (MANTOAN, 2oII, p. II).

A Educação Inclusiva ${ }^{5}$ é uma conquista recente, alicerçada em estudos e discussões que iniciaram na década de 1980 e impulsionada a partir da Conferência Mundial sobre Educação para Todos (1990), período em que começa a delinear-se enquanto uma política mundial para a inclusão.

Neste contexto, surge quatro anos depois, a Declaração de Salamanca (1994), que define princípios e práticas na área da Educação Especial e inicia-se um processo que tende a influir nas Políticas Públicas da Educação Brasileira.

No Brasil, no ano de 1999, institui-se o Decreto n. 3.298 que define uma Política Nacional para a Integração da Pessoa Portadora ${ }^{6}$ de Deficiência, onde a educação especial passa a ser considerada como uma modalidade transversal que permeia todos os níveis e modalidades de ensino (BRASIL, I999).

Dois anos depois, é estabelecida através da Resolução CNE/CEB n. 2, as Diretrizes Nacionais para a Educação Especial na Educação Básica, que afirma que os sistemas de ensino devem matricular todos os alunos, cabendo às escolas organizarem-se para o atendimento aos alunos com necessidades educacionais específicas, assegurando as condições necessárias para uma educação de qualidade para todos (BRASIL, 200I). Ou seja, é a escola que deve se adequar ao aluno atendendo as peculiaridades de cada um.

No mesmo ano, o Parecer do CNE/CP n. 9 institui as Diretrizes Curriculares Nacionais

para a Formação de Professores da Educação Básica, em nível superior, estabelecendo que a educação básica deve ser inclusiva, para atender a uma política de integração dos estudantes com necessidades educacionais específicas nas classes comuns dos sistemas de ensino e exigindo que a formação dos docentes das diferentes etapas inclua conhecimentos relativos à educação desses alunos (BRASIL, 200I).

Nessa perspectiva, a Lei n. 9.394 de 1996 - Lei de Diretrizes e Bases da Educação Nacional (LDB) priorizou esta nova visão educacional, principalmente com a revisão do

\footnotetext{
4 Neste estudo será utilizada a terminologia "Necessidades Educacionais Específicas" em vez de "Necessidades Educacionais Especiais". Isto deve-se ao fato de perceber, principalmente, através dos estudos teóricos, o quanto o termo "especiais" traz uma carga significativa de discriminação/preconceito, relacionada diretamente aos estigmas, limitações, etc., sendo que as pessoas que apresentam alguma deficiência deixam de ser vistas na sua integralidade e passam a ser reconhecidas, apenas, por suas diferenças.

5 Sassaki (1997) sinaliza que o movimento da inclusão teve início por volta de 1985 (países mais desenvolvidos), tomou impulso nos anos de 1990 (países em desenvolvimento) e evolui-se, a nível mundial, na primeira década do século XXI.

${ }^{6}$ Esta é uma forma de se referir à pessoa com deficiência que está nos documentos oficiais (Declaração de Salamanca, por exemplo). Entretanto, esta terminologia recebe críticas, inclusive das pessoas com deficiência, pois dá a ideia de que portam algo que daqui a pouco podem deixar de portar.
} 
artigo 59 que agora afiança aos educandos com necessidades específicas, a adaptação curricular, metodológica e organizacional da escola, permitindo também a terminalidade e a aceleração de acordo com as necessidades de cada pessoa.

Considerando os apontamentos citados, percebe-se que a proposta de Educação Inclusiva tem ganhado espaço nas últimas décadas, sendo incorporada como bandeira de luta em várias frentes da sociedade. Essa luta desenhada nos mais variados espaços de reflexões, sinaliza uma preocupação por parte das várias instâncias sociais com a formação humana, bem como o direito a diversidade, o diferente, o outro. Observa-se a cada dia a necessidade premente de valorizar a pessoa/aluno com deficiência não pelo que lhe falta, $e$ sim, pelo ser humano que é, sujeito social, histórico, de direitos e potencialidades, que como qualquer outro indivíduo tem uma maneira específica de ser/estar no mundo. Assim sendo, Carvalho (2014, p. 56) reafirma que "Todos somos diferentes e queremos ser reconhecidos em nossas diferenças sem sermos igualados aos demais, negando-se nossas experiências, subjetividades e nossas identidades! Pleiteamos e lutamos pela igualdade de direitos, inclusive o de sermos diferentes".

Neste sentido, muitos encontros, seminários e congressos foram realizados como forma de divulgar e orientar na elaboração e execução de ações visando uma educação de qualidade.

Do ponto de vista legal cabe ressaltar que o atendimento e abertura das escolas para alunos com necessidades educacionais específicas estão resguardados, conforme consta no artigo I da Resolução n. 4/2009:

Os sistemas de ensino devem matricular os alunos com deficiência, transtornos globais do desenvolvimento e altas habilidades/superdotação nas classes comuns do ensino regular e no Atendimento Educacional Especializado (AEE), ofertado em salas de recursos multifuncionais ou em centros de Atendimento Educacional Especializado da rede pública ou de instituições comunitárias, confessionais ou filantrópicas sem fins lucrativos (BRASIL, 2009, p. I).

$\mathrm{O}$ artigo $2^{\circ}$ da mesma Resolução apresenta o Atendimento Educacional Especializado (AEE) como recurso para complementar ou suplementar a formação do aluno por meio da disponibilização de serviços de acessibilidade e estratégias pedagógicas que eliminem as barreiras para a plena participação nas atividades escolares e como preparação para o convívio em sociedade (BRASIL, 2009).

Acredita-se que ao longo dos últimos anos, a inclusão tem contribuído para a melhoria da autoestima e valorização do aluno enquanto ser produtivo e atuante, independente de sua condição física, social ou econômica. Por isso que para romper com concepções arraigadas de que a pessoa com deficiência não consegue aprender, a Educação Inclusiva tem como objetivos acolher a todos sem distinção, oportunizar o acesso ao conhecimento e desenvolvimento das potencialidades, promover a participação na escola e na sociedade, como também garantir o direito de ser cidadão.

Diante do exposto, este estudo teve como objetivo geral evidenciar os aspectos da operacionalização da inclusão, na Educação Infantil do município de Trindade/GO, sob a ótica do professor.

A discussão desta temática - Educação Inclusiva - é de extrema importância. Assim, faz-se necessário refletir e saber como de fato a inclusão da criança com NEE acontece no 
contexto escolar. $O$ interesse então surgiu em função de algumas particularidades e, a principal delas, refere-se ao papel social da escola que legalmente deve oferecer um ensino inclusivo já nas séries iniciais. $\mathrm{O}$ que instigou a pensar como tem sido essa oferta e quem são essas crianças atendidas no município de Trindade/GO.

Ao propor tal discussão esta pesquisa se configura como relevante, visto que há poucos estudos voltados para a referida temática no município mencionado. Espera-se ainda instigar outros estudiosos a debruçarem sobre o tema.

\section{METODOLOGIA}

Trata-se de uma pesquisa de campo, de natureza qualiquantitativa. Com base em KNECHTEL (2014), a abordagem qualiquantitativa interpreta as informações quantitativas através de símbolos numéricos e os dados qualitativos por meio da interpretação das falas dos sujeitos, dentre outros. Neste contexto, as duas abordagens foram complementares, haja vista que contribuíram na compreensão do estudo proposto.

Compreendendo a pesquisa científica como "[...] um procedimento racional e sistemático que tem como objetivo proporcionar respostas aos problemas que são propostos" (GIL, 2002, p. 17), buscou-se conhecer a Educação Infantil Inclusiva no município de Trindade/GO.

Primeiramente, estabeleceu-se contato com a Secretaria Municipal de Educação (SME) de Trindade/GO, a qual demonstrou interesse na pesquisa. Em seguida, iniciou-se a busca dos documentos para os trâmites de autorização. Logo após a autorização, o projeto foi submetido ao Comitê de Ética em Pesquisa (CEP), através da Plataforma Brasil, o qual obteve a aprovação.

O estudo foi realizado com 25 professoras ${ }^{7}$ da Rede Municipal de Trindade/GO que atuam ou já atuaram na Educação Infantil e atendem ou já atenderam alunos com necessidades educacionais específicas. A faixa etária das participantes varia entre 20 a 49 anos ou mais. Todas são graduadas em Pedagogia e a grande maioria com especialização na área em que atuam, sendo que apenas duas não tem curso de pós-graduação. Quanto ao tempo de trabalho na Educação, uma parcela significativa $(\mathrm{I} 6 ; 64 \%)$ das entrevistadas atua como docente entre 5 a 20 anos e (II, 44\%) são servidoras ${ }^{8}$ do município há mais de 05 anos.

A técnica de pesquisa que possibilitou a geração de dados $^{9}$ foi um questionário semiestruturado ${ }^{10}$ on-line (via Google Forms). O questionário pode ser definido “[...] como

\footnotetext{
7 O convite à participação na pesquisa foi estendido a professores e professoras, mas somente as professoras se fizeram presentes. Convém destacar que no contato inicial com os docentes foi exposto o propósito do estudo, bem como os seus riscos, benefícios, sigilo das identidades e etc., e que todas estas informações estariam disponibilizadas no Termo de Consentimento Livre e Esclarecido.

${ }^{8}$ Das 25 docentes pesquisadas, apenas uma delas não é servidora efetiva do município.

9 Vale destacar que a pesquisa é também de caráter documental, isto é, contemplou a legislação pertinente a área da educação especial e inclusiva, bem como dados relativos (Io semestre/202I) a Secretaria Municipal de Educação de Trindade/GO.
} 
a técnica de investigação composta por um número mais ou menos elevado de questões apresentadas por escrito às pessoas, tendo por objetivo o conhecimento de opiniões, crenças, sentimentos, interesses, expectativas, situações vivenciadas etc.” (GIL, 1999, p. I28).

Os dados após coletados foram analisados à luz da ótica da análise de conteúdo, entendida como:

\begin{abstract}
Um conjunto de técnicas de análise das comunicações visando a obter, por procedimentos sistemáticos e objetivos de descrição do conteúdo das mensagens, indicadores (quantitativos ou não) que permitam a inferência de conhecimentos relativos às condições de produção/recepção (variáveis inferidas) destas mensagens (BARDIN, 20II, p. 47).
\end{abstract}

Isso significa dizer que a análise dos dados, “[...] tem como objetivo compreender o que foi coletado, confirmar ou não os pressupostos da pesquisa e ampliar a compreensão de contextos para além do que se pode verificar nas aparências do fenômeno" (JÚNIOR, MELO \& SANTIAGO, 2010, p. 34).

\title{
3 RESULTADOS E DISCUSSÃO
}

De acordo com Bardin (20II), o tratamento dos dados, a inferência e interpretação do que foi coletado na pesquisa refere-se ao momento da intuição, da análise reflexiva e crítica. Assim sendo, o resultado da análise é apresentado em dois momentos: "Os alunos assistidos com Necessidades Educacionais Específicas" e "Educação Inclusiva: desafios e possibilidades na Educação Infantil".

Antes de apresentá-la, faz-se oportuno ressaltar que a Educação Infantil da Rede Municipal de Educação de Trindade/GO é ofertada para crianças, em período integral ou parcial, em instituições educacionais próprias, sendo: ${ }_{4} 4$ Centros Municipais de Educação Infantil (CMEI's - o8 meses até 3 anos e II meses) e uma extensão do CMEI Wilma Soares de Paula, is Escolas Municipais (Pré-Escola: 4 a 5 anos e II meses) e uma instituição conveniada, Centro de Educação Infantil.

Segundo a SME, o município de Trindade/GO conta atualmente com 4.515 crianças matriculadas na rede de ensino, destas 58 são consideradas com NEE e 6 são atendidas no $\mathrm{AEE}^{\mathrm{II}}$. Os atendimentos são pautados pelas orientações das Diretrizes da SME, Plano Político-Pedagógico, Plano Educacional Individualizado, Adaptação Curricular Metodológica, espaço, materiais, entre outros.

A Rede Municipal de Educação conta com dez professores de AEE distribuídos em oito salas de atendimento especializado e 207 professores atuantes na Educação Infantil.

A Educação Infantil constitui a fase inicial do ensino básico marcada pela ludicidade, isto é, "[...] a inserção dos jogos e das brincadeiras [...] é a chave para a

ro Contendo questões abertas e fechadas, aplicado no período de or de fevereiro a 3r de março de 2021.

II $\mathrm{O}$ AEE constitui oferta obrigatória dos sistemas de ensino. Assim sendo, é disponibilizado às 58 crianças com NEE matriculadas no município, no entanto, apenas 6 são atendidas. Por ser oferecido no contraturno escolar e não ser de frequência obrigatória, a participação fica a critério das famílias. 
construção de uma aprendizagem prazerosa, eficiente, assim como a elevação da autoestima de um sujeito que está sujeito ao fracasso escolar" (PRIMO \& JUNIOR, 20I2, p. 20). Mas, para promover a aprendizagem das crianças com NEE faz-se necessário um

[...] conjunto de procedimentos, e o uso de diferentes estímulos e estratégias pedagógicas, que mexam com as estruturas mentais, despertando no aluno o desejo de aprender, a concentração, atenção, e o raciocínio lógico que podem ser desenvolvidos com a ajuda do AEE (PRIMO \& JUNIOR, 2012, p. 25).

Em outras palavras, cabe ao professor oportunizar a aprendizagem, por meio de estímulos e estratégias pedagógicas, evitando assim, a evasão escolar ou abandono e ao mesmo tempo proporcionando ao discente com NEE a autoestima e a inclusão.

\section{I Os alunos assistidos com Necessidades Educacionais Específicas}

Segundo a UNESCO (2015, p. 23) "[...] estima-se que haja entre 93 e 150 milhões de crianças com deficiências, o que aumenta o risco de serem excluídas da educação".

Partindo desta premissa, buscou-se verificar quem são as crianças com NEE atendidas pelas interlocutoras desta pesquisa. No entanto, antes de adentrar nesta particularidade, vale destacar que (14; 56\%) docentes participantes deste estudo assistem alunos que frequentam a pré-escola (4 a 5 anos); (Io; 40\%) atendem crianças de zero a três anos nas creches, ou seja, nos Centros Municipais de Educação Infantil e (I; 4\%) docente havia assumido recentemente a coordenação escolar e por essa razão, não estava exercendo a prática em sala de aula. Neste contexto, doze docentes têm em sua turma, um número significativo de alunos com necessidades educacionais específicas (até 03 alunos).

Levando-se em conta que há um público considerável de educandos que apresentam NEE, faz-se relevante mencionar as concepções de uma escola inclusiva, onde estas crianças devem ser tratadas:

[...] na perspectiva de uma escola para todos, que não se reduzem a pessoas rotuladas por professores, ou por especialistas, que os condenam a categorizações e hierarquizações, impostas por aparatos psicológicos e pedagógicos (testes, provas, coeficientes, padrões de desenvolvimento, desempenho acadêmico, entre outros). Cada aluno é um sujeito, cuja complexidade não se mede de fora e que precisa de situações estimuladoras para que cresça e avance em todos os aspectos de sua personalidade, a partir de uma construção ao mesmo tempo social e pessoal, que vai se definindo e transmutando a sua identidade (MANTOAN, 20II, p. II).

$\mathrm{Na}$ escola inclusiva os alunos são sujeitos de direito. Ou seja, não devem ser rotulados a partir de suas necessidades, mas respeitados a partir de suas identidades. E ainda:

[...] garantir-lhes um AEE paralelo, complementar, de preferência na escola comum, para que não sejam desconsideradas as especificidades de alguns aprendizes, quando apresentam alguma deficiência. A escola comum não pode ser substituída pelo ensino especial na oferta do ensino acadêmico, pois este é complementar à formação do aluno com deficiência e trata primordialmente das limitações que a deficiência lhes acarreta quando estudam em turmas do ensino regular (MANTOAN, 2oir, p. 3i). 
Para mapear as necessidades educacionais específicas trabalhadas na Educação Infantil (EI), da Rede Municipal de Trindade/GO, foi disponibilizado às participantes uma lista composta de sete tipos de necessidades educacionais e elas puderam optar/escolher por mais de um quesito.

Tabela - Tipos de Necessidades Educacionais Específicas

\begin{tabular}{cc}
\hline Necessidades Educacionais Específicas & Quantidade \\
\hline Transtornos globais do desenvolvimento (TGD) & I4 \\
Deficiência intelectual & 8 \\
Deficiência física & 7 \\
Deficiência auditiva & 6 \\
Altas habilidades ou superdotação & 6 \\
Deficiência visual & 6 \\
Deficiência múltipla & 5 \\
\hline
\end{tabular}

Fonte: Pesquisa de Campo (2021).

A tabela acima apresenta dados interessantes: primeiro revela que a Rede Municipal de Educação de Trindade/GO tem como maior público de alunos com NEE aqueles que apresentam Transtornos Globais do Desenvolvimento (TGD). Eles

[...] apresentam um quadro de alterações no desenvolvimento neuropsicomotor, comprometimento nas relações sociais, na comunicação ou estereotipias motoras. Incluem-se nessa definição alunos com autismo clássico, síndrome de Asperger, síndrome de Rett, transtorno desintegrativo da infância (psicoses) e transtornos invasivos sem outra especificação (BRASIL, 2009, p. I).

Esses sujeitos com TGD tiveram uma maior garantia de qualidade na escolarização com a Política Nacional de Educação Especial na Perspectiva da Educação Inclusiva. Segundo a APA (2002), a categoria $\mathrm{TGD}^{\mathrm{I2}}$ refere-se aos transtornos que se caracterizam por prejuízos severos e invasivos em diversas áreas do desenvolvimento, provocando um desvio acentuado em relação ao nível de desenvolvimento ou idade mental do indivíduo, o que afeta a sua adaptação social, educacional e de comunicação.

Em função destas particularidades a Lei n. 12.764/2012 menciona no artigo $3^{\circ}$, em seu parágrafo único, que em caso de necessidade "[...] a pessoa com transtorno do espectro autista [...] terá direito a acompanhante especializado" (BRASIL, 20I2).

Em segundo lugar destacam-se as crianças com Deficiência Intelectual que "[...] possuem condições estruturais e funcionais que comprometem a adaptação ao ambiente e a ampla aquisição de informações" (SANTOS, 2012, p. 937). Em relação a esse tipo de deficiência a escola tem se apropriado, em grande medida, do laudo clínico para planejar as

I2 “Os Transtornos Globais do Desenvolvimento, que incluíam o Autismo, Transtorno Desintegrativo da Infância e as Síndromes de Asperger e Rett foram absorvidos por um único diagnóstico, Transtornos do Espectro Autista" (ARAÚJO \& NETO, 2014, p. 7o). 
práticas educacionais, deixando de considerar as particularidades da criança, afinal a inclusão:

[...] não pode ser fruto de imposições aleatórias, mas um processo que o indivíduo concretiza em si mesmo, na interação e na convivência com os outros. Daí a importância e a necessidade do sujeito com necessidades especiais acreditar na possibilidade de construir uma autoimagem positiva, descobrindo-se como valor, cheio de potencialidades e dinamismo (PIRES, 2000, p. 55).

Em terceiro lugar destacam-se as crianças com Deficiência Física que exigem cuidados diferenciados, "[...] na medida em que os transtornos de controle do movimento e da postura e complicações associadas (vesicais, intestinais, musculoesquelético, entre outras) poderão interferir diretamente na independência e autonomia das mesmas" (MELO \& FERREIRA, 2009, p. 123). Paralelamente, exige-se do ambiente escolar uma estrutura de acessibilidade, no que se refere a parte física e pedagógica (MELO \& FERREIRA, 2009).

Empatados em quarto lugar estão os alunos com Deficiência Auditiva, Altas Habilidades ou Superdotação e Deficiência Visual. Aos alunos com Deficiência Auditiva, recomenda-se que o processo de escolarização ${ }^{13}$ e a aprendizagem aconteça por meio da Língua Brasileira de Sinais - LIBRAS ${ }^{14}$ e da Língua Portuguesa.

As línguas de sinais são línguas naturais porque, como as línguas orais, surgiram espontaneamente da interação entre pessoas e porque devido à sua estrutura permitem a expressão de qualquer conceito - descritivo, emotivo, racional, literal, metafórico, concreto, abstrato - enfim, permitem a expressão de qualquer significado decorrente da necessidade comunicativa e expressiva do ser humano (BRITO, 2010, p. 2).

A Libras possui cinco parâmetros formativos: “[...] a configuração da(s) mão(s); o ponto de articulação; o movimento; a orientação/direcionalidade e a expressão facial e/ou corporal" (FELIPE \& MONTEIRO, 2007, p. 2I-23). Ou seja, é uma língua que desenvolve processos articuladores que abrange partes do corpo ${ }^{15}$ passíveis de movimentos nos quais,

${ }^{13}$ O Decreto n. 5.626/2005 garante às pessoas com surdez/deficiência auditiva o direito à Educação Bilíngue. Educação esta que considera a LIBRAS como língua natural e a Língua Portuguesa como segunda língua, para a

aquisição da leitura e escrita. No entanto, mesmo sendo um direito, esta realidade não se faz presente no contexto

escolar, pois percebe-se alunos concluindo o ensino médio sem o domínio da leitura e da escrita, ou muitas vezes

analfabetos na segunda língua (Moret \& Mendonça, 2016).

${ }^{14}$ Art. 3. A Libras deve ser inserida como disciplina curricular obrigatória nos cursos de formação de professores para o exercício do magistério, em nível médio e superior, e nos cursos de Fonoaudiologia, de instituições de ensino, públicas e privadas, do sistema federal de ensino e dos sistemas de ensino dos Estados, do Distrito Federal e dos Municípios (BRASIL, 2005).

is Durante o processo de comunicação, a Língua Brasileira de Sinais utiliza além das mãos, outras partes do corpo, tais como a cabeça, a face e o tronco. 
integrados aos demais formam um contexto de significados, com grande riqueza de sentimentos, emoções etc.

O Decreto n. 5.626/2005 preconiza em seu artigo $22^{16}$ que as instituições de ensino devem se organizar para a inclusão dos alunos surdos ou com deficiência auditiva, dispondo de professores bilíngues ${ }^{17}$. Todavia,

[...] a formação de professores para inclusão das pessoas surdas, estabelecido pelo Decreto 5.626/o5, tem se mostrado insuficiente para preparar o professor para ser, de fato, bilíngue e munido de conhecimentos necessários para atender às necessidades dos alunos surdos e, por desconhecimento, o professor exclui-se desse processo, transferindo para o tradutor/intérprete a responsabilidade pelo aprendizado desses alunos (PIRES, 2018, p. 8I).

Frente a esta constatação, percebe-se o quanto a formação continuada do professor torna-se uma ferramenta imprescindível para auxiliar no processo de aprendizagem das crianças no contexto educacional inclusivo.

No que se refere aos alunos com Altas Habilidades/Superdotação, estes são alunos precoces, que têm habilidades e potenciais (talento, criatividade e etc.) diferenciados perante as demais crianças da mesma idade, mas que nem sempre são percebidos pelas instituições de ensino, fator que compromete diretamente à aprendizagem (PÉREZ \& FREITAS, 20II).

Já os alunos que apresentam Deficiência Visual são aqueles que possuem pouca ou nenhuma capacidade de enxergar, usam lentes corretivas ou aproveitam os resíduos de visão no seu dia-dia. Caracterizando a cegueira, a baixa visão e a visão subnormal (FRÓES, 2015)

Por fim, aparecem as crianças com Deficiência Múltipla. Este tipo de deficiência pode ser conceituada por um conjunto de duas ou mais deficiências (de ordem física, sensorial, mental, emocional ou de comportamento social) associadas (BRASIL, 2006).

Todas as necessidades educacionais específicas elencadas e mapeadas na Educação Infantil do município de Trindade/GO demandam: suporte pedagógico oferecido no AEE,

${ }^{16}$ Art. 22. As instituições federais de ensino responsáveis pela educação básica devem garantir a inclusão de alunos surdos ou com deficiência auditiva, por meio da organização de: I - escolas e classes de educação bilingue, abertas a alunos surdos e ouvintes, com professores bilingues, na educação infantil e nos anos iniciais do ensino fundamental; II - escolas bilíngues ou escolas comuns da rede regular de ensino, abertas a alunos surdos e ouvintes, para os anos finais do ensino fundamental, ensino médio ou educação profissional, com docentes das diferentes áreas do conhecimento, cientes da singularidade linguística dos alunos surdos, bem como com a presença de tradutores e intérpretes de Libras - Língua Portuguesa. § Io São denominadas escolas ou classes de educação bilingue aquelas em que a Libras e a modalidade escrita da Língua Portuguesa sejam línguas de instrução utilizadas no desenvolvimento de todo o processo educativo [...]” (BRASIL, 2005).

${ }^{17}$ A proposta de inclusão escolar dos alunos surdos/deficiência auditiva prescreve a necessidade de professores bilíngues. No entanto, mesmo a LIBRAS sendo uma disciplina curricular obrigatória para os cursos de formação de professores (Decreto n. 5.626/2005), com carga horária média de 55 horas, ela oferece apenas conhecimentos introdutórios, portanto, não é suficiente para capacitar os futuros docentes para atuarem no processo de escolarização dos alunos surdos (QUADROS \& CAMPELO, 20Io). 
conhecimento teórico com fins de fundamentar a prática docente para que promovam o desenvolvimento desses alunos, metodologias de ensino específicas, planejamento educacional personalizado. E ainda, tecnologia assistiva "[...] que engloba produtos, recursos, metodologias, estratégias, práticas e serviços que objetivam promover a funcionalidade, relacionada à atividade e à participação da pessoa com deficiência, [...]" (BRASIL, 2007, p. 3). Isso porque o referido público demanda complexidade do trabalho pedagógico, habilidades específicas e outras particularidades. Consequentemente, para atendê-lo, faz-se necessário investimento na formação docente para responder qualitativamente na escola inclusiva.

Isto posto, a próxima seção evidencia como as interlocutoras concebem a Educação Inclusiva e como o processo de inclusão das crianças com NEE tem se configurado nas unidades escolares do município.

\subsection{Educação Inclusiva: desafios e possibilidades na Educação Infantil}

Segundo o Relatório de Monitoramento Global de Educação para Todos (200o2015), o acesso de crianças com deficiências à escola é muitas vezes "[...] limitado pela falta de entendimento sobre as diferentes formas de debilidades e as necessidades específicas das crianças nesses contextos, pela falta de formação dos professores e de infraestrutura física, além de atitudes discriminatórias [...]" (UNESCO, 2015, p. 23).

Partindo dessa perspectiva, buscou-se verificar as concepções a respeito do tema Educação Inclusiva, considerando a ótica das interlocutoras ${ }^{18}$ atuantes na Rede Municipal de Ensino de Trindade/GO.

Primeiramente, observou-se que algumas das entrevistadas ${ }^{19}$ tiveram dificuldade em explicar, atribuindo a Educação Inclusiva frases vagas que remetem ao termo desenvolvimento, todavia, sem delimitá-lo com clareza e objetividade:

\footnotetext{
De extrema importância para o desenvolvimento da criança (Maria Cecília, Regente, 2021)

É muito importante a inclusão no desenvolvimento da criança (Maria Vitória, Regente, 2021).

Faz necessário que muitos professores compreendam a verdadeira educação inclusiva (Maria Carolina, Regente, 2021).
}

Percebe-se uma certa falta de clareza sobre os princípios do ideário da educação inclusiva: o direito à educação; o direito à igualdade de oportunidades; o que não significa um "um modo igual" de educar a todos e sim dar a cada um o que necessita, em função de suas características e necessidades individuais; escolas responsivas e de boa qualidade; o

\footnotetext{
I8 Considerando os critérios éticos da pesquisa, todas as interlocutoras estão identificadas por nomes fictícios.

19 Todas as respostas das docentes estão grafadas conforme constaram no questionário.
} 
direito à aprendizagem e o direito à participação (CARVALHO, 2009; OLIVEIRA, 20Io, SOUZA, 2019).

Em contrapartida, a maioria das entrevistadas concebem a Educação Inclusiva associada ao preconizado a sua legislação concernente:

Incluir a criança no ambiente escolar, para que se sinta segura e alcance êxito no seu desenvolvimento cognitivo e intelectual (Maria Alice, Regente, 202I).

Promover uma base para a criança desenvolver as habilidades de aprendizagem, enfatizando o social, ético, cidadania, lúdico, afetividade e cognitivo. No qual irá trazer benefícios, crescimento e desenvolvimento para toda a vida da criança (Maria Beatriz, Regente, 202I).

Educação Inclusiva em meu ver, é possibilitar a criança/aluno meios para que ela participe ativamente do processo de aprendizagem, mas respeitando suas limitações e buscando aperfeiçoar suas habilidades. Incluir vai muito além de atender apenas as necessidades de uma criança com alguma deficiência. Incluir é olhar para a criança como um todo, considerando suas necessidades, seus anseios, sua história, sua cultura, seu meio social. É olhar para as partes e ao mesmo tempo olhar para o todo. É buscar respeitar as limitações, porém sem deixar de abrir caminhos para as descobertas, para a aprendizagem. É ver a criança com alguma deficiência como parte do grupo. E o grupo ver essa criança como um membro seu (Maria Helena, Regente, 2021).

A educação inclusiva tem uma responsabilidade muito grande nesses últimos tempos uma vez, que possibilita uma educação de qualidade com maior preparação dos professores e equipe educacional para receber as crianças com necessidades especiais, além de possibilitar a socialização, a participação e a inclusão dessas crianças nas escolas. Possibilitando o direito de acesso e trabalhando o respeito com todos. Uma vez que considero que todos nós temos uma necessidade especial que precisamos de ajuda em algum momento (Maria Julia, Regente, 202I).

As falas acima demonstram que incluir não se limita ao acesso à escola, mas que esta escolarização oportunize a criança benefícios que perpassam pelo desenvolvimento cognitivo, afetivo, socialização e outros. Por serem alunos, muitas vezes até "rotulados" e não se adequarem a "normalidade", cada um possui necessidades pontuais que merecem/devem ser consideradas num contexto inclusivo.

Isso significa dizer que a escola inclusiva é um espaço educacional de todos: sentimento de pertencimento; maior qualidade de educação para todos e combate a todas as formas de discriminação. Com isso procura-se garantir ocasiões de múltiplas interações nos ambientes das creches e pré-escolas, não excluindo de forma alguma a criança com necessidades educacionais específicas, de modo que todas as crianças tenham a oportunidade de aprender com as contribuições de cada um de seus colegas, em uma relação de alteridade (ALVES, 2008; OLIVEIRA, 2010; SOUZA, 2019).

\section{Algumas interlocutoras destacaram:}

Ainda estamos caminhando nesse processo, apesar de se tratar a educação como inclusiva, vejo que em muitas instituições não tem suportes necessários para cumprir com a acessibilidade a todos (Maria Laura, Regente, 2021). 
Acredito que nem todos os profissionais estão preparados, falta conhecimento (Maria Flor, Regente, 2021).

Um desafio com tentativas pois falta principalmente o tempo exclusivo ao educando, material adequado, espaço, professores e auxiliar qualificado (Maria Clara, Regente, 202I).

A fala destas docentes chama atenção ao pontuarem sobre a falta de suporte necessário para o cumprimento do recurso da acessibilidade física e pedagógica, elementos básicos para a inclusão. Além disso, agrega a estes o despreparo de alguns profissionais no que concerne ao processo inclusivo.

Constata-se então, a partir destas sinalizações, que o processo de escolarização das crianças só será facilitado na medida em que:

[...] sejam garantidas às escolas as condições institucionais e materiais necessárias para o desenvolvimento do processo de escolarização de todos os alunos; seja propiciada ao professor a qualificação profissional e as condições materiais que lhe possibilitam distinguir e trabalhar pedagogicamente as diferentes formas de aprender que os alunos apresentam em uma mesma sala [...] (TIBALLI, 2016, p. i58).

Ao serem indagadas sobre a legislação que versa sobre a Educação Inclusiva apenas ( $;$;\%) uma participante disse não conhecer. Isso significa que sabem que a educação inclusiva deve ser entendida para além da educação especial, pois ela prima por uma educação pautada pela igualdade de oportunidades e também pela equidade, ou melhor, uma escola que oportunize aos alunos com NEE não somente possibilidade de acesso, mas que este acesso seja garantido por meio de recursos e metodologias que contribuam em seu processo formativo.

A igualdade diz respeito aos direitos humanos e não às características das pessoas, enquanto seres que sentem, pensam e apresentam necessidades diferenciadas $e$ que, por direito de cidadania, devem ser compreendidas, valorizadas e atendidas segundo suas exigências biopsicossociais individuais. Em decorrência, fazem jus à equiparação de oportunidades de acesso, ingresso e permanência, com êxito, na escola, buscando-se ultrapassar seus limites, até porque desconhecemos a extensão da potencialidade humana! Refiro-me às oportunidades que qualquer escola deve garantir, a todos, oferecendo-lhes diferentes modalidades de atendimento educacional que permitam assegurar-lhes o êxito na aprendizagem $e$ na participação. A isso chamamos de eqüidade que, no fundo, reconhece as diferenças individuais e a importância do trabalho na diversidade, com espírito democrático, isto é, plural (CARVALHO, 2009, p. I6-17).

Quando questionadas se a escola onde atuam está preparada para atender alunos com NEE, os números revelados são contraditórios: (II; 44\%) disseram que sim e (I4; 56\%) destacaram que não. Essa diferença pode ser explicada já que nem todas as professoras participantes possuem alunos com NEE, ou seja, apenas doze respondentes (48\%) afirmaram ter em sua turma crianças com NEE.

Considerando o quantitativo de respondentes que afirmaram que a unidade escolar em que trabalham está apta a atender as crianças com NEE (II; 44\%), subentende-se que o acesso à aprendizagem e o desenvolvimento escolar estão garantidos e os alunos são colocados em um patamar de sucesso e de igualdade. E ainda, que há subsídios suficientes 
para incentivar o desenvolvimento das potencialidades. Nesse processo, a prática fomenta o fazer, assim os professores provam "[...] a si próprios e aos outros que são capazes de ensinar. A experiência fundamental tende a se transformar, em seguida, numa maneira pessoal de ensinar, em macetes da profissão, em habitus, em traços da personalidade profissional" (TARDIF, 2002, p. 5I).

Contudo, considerando o outro percentual (I4;56\%) apontado, faz-se necessário mencionar as colocações de Mittler (2003, p. 236) que asseveram a importância de:

[...] uma mudança de cultura e de organização da escola para assegurar acesso e participação para todos os alunos [...]. A inclusão não é a colocação de cada criança individual nas escolas, mas é criar um ambiente onde todos possam desfrutar o acesso e o sucesso no currículo e tornarem-se membros totais da comunidade escolar e local, sendo, desse modo, valorizados.

E também, as observações de Drago (2014, p. 19):

A escola, para grande parte das crianças brasileiras, é o único espaço de acesso aos conhecimentos universais e sistematizados socialmente, ou seja, é o lugar que pode lhes proporcionar condições de se desenvolver e de se tornar cidadãos, alguém com identidade social e cultural.

Destarte, percebe-se o quanto é relevante ter um ambiente escolar propício a atender as necessidades de todos os alunos, ou seja, um ambiente inclusivo que oportunize o aprendizado

e seja transformador na vida dos educandos, possibilitando-os a exercerem dignamente sua cidadania.

Ao serem perguntadas sobre o envolvimento da gestão escolar (diretores, coordenadores) no que se refere a inclusão, as respondentes foram unânimes em dizer que I00\% dos gestores atuam favoravelmente em direção ao processo inclusivo. Isso revela que:

Uma nova escola é perfeitamente possível, porque muitos são os professores que, apoiados pelas famílias e assessorados por seus diretores e supervisores, estão acreditando em outros modos de pensar a educação e de fazê-la acontecer na sala de aula, onde cada um tem a sua identidade respeitada e onde velhas práticas possam ser transformadas em novas oportunidades de aprendizagem, para todos os alunos, mais ou menos deficientes (SARTORETTO, 20II, p. 82).

Esse envolvimento faz toda a diferença, pois promove novas oportunidades de aprender. Visto que a escola inclusiva contempla a todos, além disso, ela "[...] direciona-se para um ensino que, além de reforçar os mecanismos de interação solidária $e$ procedimentos cooperativos, auxilia o ser humano a se ver e se perceber como parte de um todo que independe de suas características físicas" (DRAGO, 2014, p. 78).

Foi perguntado às docentes se no planejamento das aulas todos os alunos são incluídos, inclusive os que apresentam NEE. A maioria delas (2I; 84\%) disse conseguir durante o planejamento das suas aulas, contemplar todos os alunos da turma, independentemente de suas especificidades educacionais. Isso significa que as atividades são pensadas e articuladas também a cada NEE, de forma que a dinâmica das aulas vai contribuindo para a inserção de todo o alunado. Assim, o professor não se limita ao falar, ao ditar, ao copiar, mas. 
[...] partilha com seus alunos a construção/autoria dos conhecimentos produzidos em uma aula; trata-se de um profissional que reúne humildade com empenho e competência para ensinar. $\mathrm{O}$ ensino expositivo foi banido de sua sala de aula, na qual todos interagem e constroem ativamente conceitos, valores, atitudes. Esse professor arranja e explora os espaços educacionais com seus alunos, buscando perceber o que cada um deles consegue aprender do que está sendo estudado e como procedem ao avançar nessa exploração (MANTOAN, 20II, p. 65).

Esse saber compartilhado favorece o aprender porque ao "[...] aproximar as crianças das produções humanas em toda a sua complexidade, recortando, porém, aquilo que pode fazer sentido para elas é que vai fazê-las avançar nos conhecimentos que já possuem, [...]" (ORTIZ, 2oII, p. 54). Além disso, o compartilhar dos saberes valoriza o que a criança sabe e o que ela produz, desafiando-a construir e estabelecer "relações e hipóteses [...], organizando esses saberes de forma significativa, criativa e pessoal, fará com que o terreno fértil da Educação Infantil seja de fato semeado e produza a sustança cultural de que as crianças precisam e têm direito" (ORTIZ, 20II, p. 57).

Ao considerar no planejamento a realidade sociocultural do aluno, o interesse é despertado, as curiosidades surgem e a vontade de aprender cresce (FREIRE, 1987).

Ao serem questionadas em relação a questão da acessibilidade, (23; 92\%) das respondentes disseram que esta constitui um elemento importantíssimo. Percebe-se então, a partir desta sinalização docente, que a acessibilidade é reconhecida como um "recurso" facilitador da inclusão, pois possibilita ao aluno com NEE condições de acesso ao espaço escolar, a comunicação, a utilização de materiais didático-pedagógicos e outros, enfim, oportuniza a aprendizagem e a convivência no cotidiano social.

Neste sentido, vale reforçar o conceito de acessibilidade constante no Decreto $n$. $5.296 / 2004$, em seu artigo 8 , inciso I:

[...] condição para utilização, com segurança e autonomia, total ou assistida, dos espaços, mobiliários e equipamentos urbanos, das edificações, dos serviços de transporte e dos dispositivos, sistemas e meios de comunicação e informação, por pessoa portadora de deficiência ou com mobilidade reduzida (BRASIL, 2004).

Levando em conta os dados apontados, observa-se que apenas duas participantes (2; 8\%) mencionaram que a acessibilidade não constitui um elemento de necessidade na escola onde atuam. Vale lembrar que, mesmo que suas escolas não atendam alunos com NEE, certamente ela recebe o mais variado público, dentre eles, pessoas com deficiência.

Ao serem perguntadas a respeito da presença dos alunos com NEE na sala de aula regular, $(23 ; 92 \%)$ das respondentes consideraram necessária, enquanto que $(2 ; 8 \%)$ preferiram não opinar. Ao destacarem tal necessidade, significa dizer que as referidas professoras estão conscientes do papel social da diversidade, e ainda, sabem da importância das relações interpessoais na construção de seres mais humanos.

[...] As crianças aprendem muitas habilidades acadêmicas [...] e também habilidades da vida diária, de comunicação e sociais [...] através das interações com seus pares. Todos os alunos, incluindo aqueles com deficiências, precisam de interações professor-aluno e aluno-aluno que moldem habilidades acadêmicas e sociais. [...] embora uma criança com deficiência possa não ser capaz de absorver todo o currículo da educação regular, ela pode beneficiar-se das experiências no ambiente educacional regular $[. .$.$] . As pessoas com deficiência ficam preparadas$ 
para a vida na comunidade quando são incluídas nas escolas e nas salas de aula (STAINBACK \& STAINBACK, I999, p. 23).

Neste sentido, percebe-se a indispensável presença de todas as crianças, sem exceções, no contexto regular de ensino, pois possibilitam as interações, o aprender juntos, oportunizando não apenas a aprendizagem de conteúdos acadêmicos, mas a experiências singulares que certamente são levadas por toda a vida.

Quando questionadas se a escola em que atuam está aberta para a recepção dos alunos da inclusão, $(2 \mathrm{I} ; 84 \%)$ das respondentes afirmaram que sim. Infere-se a partir desta sinalização docente que as instituições de ensino do munícipio de Trindade/GO, investem no sentido de contribuírem para a

\section{[...] construção de personalidades humanas autônomas, críticas, nos quais as crianças aprendem a ser pessoas. Nesses ambientes educativos ensina-se os alunos a valorizar a diferença, pela convivência com seus pares, pelo exemplo dos professores, pelo clima socioafetivo das relações estabelecidas em toda a comunidade escolar - sem tensões, competição de forma solidária e participativa. Escolas assim concebidas não excluem nenhum aluno de suas classes, de seus programas, de suas aulas, das atividades e do convívio escolar mais amplo. São contextos educacionais em que todos os alunos tem possibilidade de aprender frequentando uma mesma e única turma (MANTOAN, 20II, p. 6I).}

$\mathrm{Na}$ perspectiva de saber a contribuição da família no processo de ensino e aprendizagem dos alunos com NEE, as respondentes afirmaram que esta parceria é de grande relevância, tanto no sentido de favorecer o conhecimento em relação à criança quanto cooperar na escolha das melhores práticas pedagógicas.

A grande maioria ( 15 ; 60\%) considera a família como uma aliada na construção do processo de conhecimento fomentado pela escola. Ou seja, as educadoras reconhecem a importância do trabalho conjunto, porque esta parceria "[...] família e escola/creche, juntas, podem promover situações complementares e significativas de aprendizagem e convivência que realmente vão ao encontro das necessidades e demandas das crianças de ambas as instituições" (BHERING \& DE NEZ, 2002, p. 63-64).

Complementando, ( escolar, contribui para uma melhor escolha das práticas pedagógicas para o atendimento das crianças com necessidades educacionais específicas. O que permite inferir a necessidade contínua de se criar e estabelecer projetos que envolvam a família/escola no intuito de fortalecer os laços. Visto que,

[...] a interação entre a criança pequena com deficiência, sua família, a instituição de Educação Infantil e a Educação Especial é de extrema relevância. Acredita-se que, em uma maior interação, os diferentes cuidadores têm a oportunidade de conhecer melhor a criança, estabelecendo critérios educativos comuns, discutindo modelos de intervenção, melhorando a relação com a criança e tornando mais claras as especificidades na função educativa de cada um (SOUZA, 2019, capítulo I).

Desse modo, é salutar promover a interação entre estas instituições, para conjuntamente/continuamente falarem a mesma língua. Em outras palavras, é fundamental estreitar a parceria com a família, pois é ela quem informará o histórico e a condição da criança: 


\begin{abstract}
Diagnósticos precisos são importantes e devem ser respeitados, principalmente se puderem orientar a melhor forma de atender às necessidades do aluno, mas não podem ser confundidos com rótulos e principalmente não devem servir para reduzir o aluno a determinada condição, como "o autista", "o deficiente mental", “o TDAH”, “o dislexo”, entre outros. [...] Sempre que possível, os profissionais que acompanham o aluno e seus familiares devem ser contatados para ampliar a possibilidade de conhecimento da situação e de verificação de possibilidades reais de atendimento às necessidades apresentadas e respeito às especificidades do aluno e de seus familiares (EMÍLIO \& CINTRA, 20II, p. 85-86).
\end{abstract}

Esse diagnóstico apresentado pela família contribui diretamente no planejamento da prática pedagógica direcionada aos alunos com necessidades educacionais específicas.

Quando questionadas sobre os recursos ofertados pela escola para o processo inclusivo, foi disponibilizado às participantes uma lista composta de cinco tipos de recursos (salas de aula espaçosas, ventiladas e com luminosidade adequada; ambientes externos adequados à todas as crianças; tecnologias assistivas; mobiliário específico e material didático para atender as particularidades de cada aluno). Neste quesito, poderiam marcar mais de uma opção.

Os dados apontam que a infraestrutura (salas de aula e ambientes externos) tem sido o principal (40\%) recurso facilitador do processo inclusivo de alunos com NEE. Apesar de serem fundamentais não conseguem por si só garantir a inclusão. Agora se observa que o material didático representa um percentual de $8 \%$, o que leva a indagar: esse quantitativo não compromete suas escolhas a proposta a desenvolver? Já que os materiais didáticos, como os jogos educativos, por exemplo,

Estão orientados para estimular o desenvolvimento cognitivo e são importantes para o desenvolvimento do conhecimento escolar mais elaborado - calcular, ler e escrever. São jogos fundamentais para a criança deficiente mental por iniciá-la em conhecimentos e favorecer o desenvolvimento de funções mentais superiores prejudicadas (IDE, 2008, p. 102).

Isso significa que com limitados recursos pedagógicos dificilmente consegue-se favorecer o desenvolvimento individual do educando com NEE.

Em relação ao mobiliário, o percentual ficou em $12 \%$. Enquanto recurso de acessibilidade, o mobiliário adequado/adaptado ao aluno com NEE constitui um meio fundamental porque assegura condições de acesso e aprendizagem, conforme preconizado pela legislação (BRASIL, 2008).

No que se refere à Tecnologia Assistiva, segundo as respondentes corresponde a $20 \%$, ou seja, esse recurso favorece à aprendizagem, podendo ser todo recurso que " $[\ldots]$ proporcione a ampliação das habilidades, autonomia e maior qualidade de vida. [...] incorpora metodologias, estratégias, práticas e serviços. Desse modo, ela é classificada de acordo com os objetivos funcionais a que se destina" (ROCHA \& PAIVA, 2015, p. 54).

Neste sentido, a tecnologia assistiva sinaliza caminhos e perspectivas, pois é considerada como instrumento mediador a partir da oferta de recursos para o "empoderamento" dos educandos com necessidades educacionais específicas, oportunizando melhor comunicação, mobilidade, inclusão, acessibilidade e outros.

Outra indagação feita às interlocutoras foi sobre o processo inclusivo no contexto escolar. Os dados sinalizam que este processo se estabelece a partir das várias leituras: (II; 
44\%) acreditam que a inclusão acontece e contempla todo o alunado; $(5 ; 20 \%)$ interpretam que acontece parcialmente e atinge alguns alunos; (3; 12\%) disseram que a inclusão não acontece, ocorre apenas a integração entre alunos com NEE e regulares e um número significativo $(6 ; 24 \%)$ não opinou, ou seja, não disseram se a inclusão acontece ou não na escola.

[...] não cabe mais questionar se a criança deve estar no ensino regular ou na escola especial, mas de assumir que se ela está usufruindo de seu direito à educação, então que se realize um projeto educacional que consolide este direito com dignidade. E este projeto não pode desconsiderar a construção de uma concepção de educação e de escola inclusiva que seja comum em objetivos, sensível e atrelado às discussões tanto do papel do professor, quanto do gestor, das famílias, da criança e de tantos outros sujeitos envolvidos. Nesta construção devem ser trabalhados conceitos como diferença, alteridade, diversidade, igualdade, equidade, identidade, subjetividade, por exemplo, e não apenas métodos e diagnósticos (SOUZA, 2019, capítulo 6).

Independente ser educação especial ou regular a criança deve ser tratada com respeito e dignidade. Cabe ao professor trabalhar a diversidade começando pelo "[...] reconhecimento das diferenças e na paridade de direitos que, na escola, traduzem-se como aprendizagem e participação e não apenas como presença física nesta ou naquela modalidade de atendimento educacional escolar" (CARVALHO, 2014, p. 23).

Ao ser perguntado: o que é necessário para o ensino inclusivo na Educação Infantil se efetivar, foi disponibilizado às participantes uma lista composta de oito itens (políticas públicas, atenção da equipe multidisciplinar, adaptações na estrutura física das escolas, formação continuada, adaptações curriculares e metodologias, interação entre saúde e educação, participação da família ou todas as opções anteriores) e elas puderam optar/escolher por quantos quisessem

Figura - Ações para a Inclusão na Educação Infantil

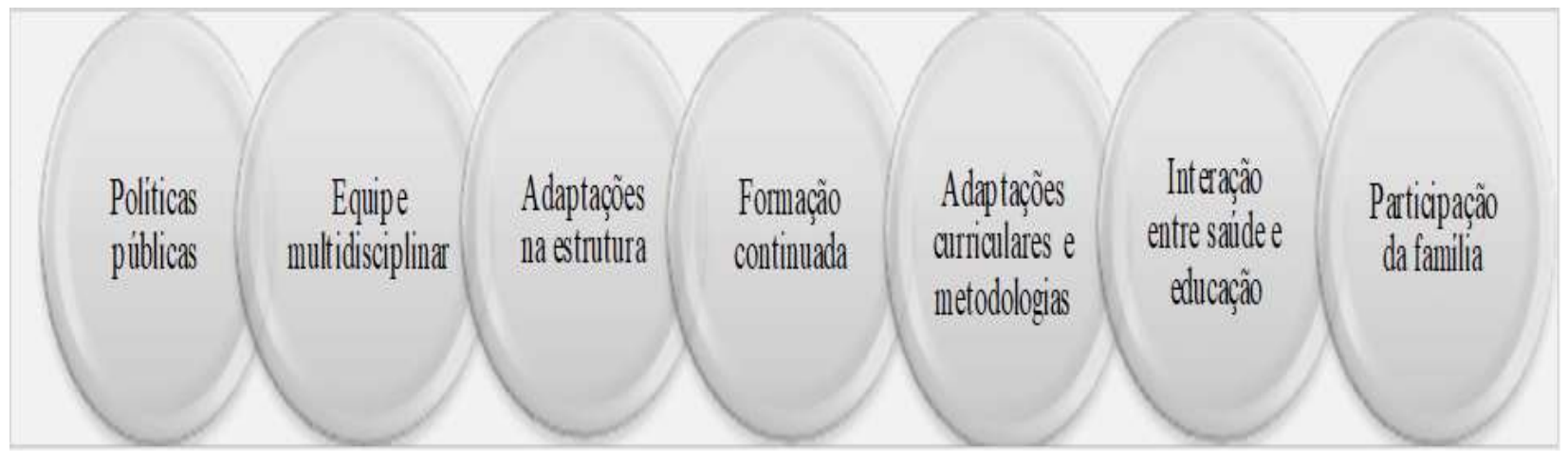

Fonte: Pesquisa de Campo (2021).

A maioria das interlocutoras respondeu (23; 92\%) que é um conjunto de ações articuladas que precisam ser sistematizadas para promover a inclusão na EI. 
É notório que sem a efetivação de políticas públicas ${ }^{20}$, a educação inclusiva não toma forma e nem se legitima no contexto educacional.

E dentro da unidade escolar há outros elementos que precisam dialogar para que o todo funcione: a equipe multidisciplinar tem um papel fundamental, a escola precisa de adaptações na infraestrutura (rampa, piso tátil, banheiros adaptados, mobiliário adequado, etc.), os professores necessitam de formação continuada para dar conta de atender as especificidades inerentes aos alunos com NEE. Ao mesmo tempo faz-se necessário readaptar o currículo e as metodologias. Paralelamente, estreitar relações intersetoriais entre saúde e educação, e ainda, contar com o apoio da família no processo formativo proposto.

Quando perguntadas sobre o papel da interação junto às crianças com NEE, as respondentes foram unânimes (25; 100\%) em dizer que a interação com outras crianças favorece o desenvolvimento cognitivo e afetivo, bem como contribui no processo de ensino e aprendizagem. Isto é,

É na interação social que a criança entrará em contato e se utilizará de instrumentos mediadores, desde a mais tenra idade. Talvez o primeiro deles seja o próprio seio materno. A necessidade e o desejo de decifrar o universo de significados que a cerca leva a criança a coordenar ideias e ações a fim de solucionar os problemas que se apresentam (MACHADO, 2004, p. 28).

A interação tem papel importantíssimo no processo de ensino e aprendizagem. E cabe ao professor promovê-la e mediá-la.

Em busca de conhecer que são os profissionais de apoio que dão suporte a Educação Infantil Inclusiva, foi disponibilizado às participantes uma lista composta de seis profissionais (Professor de Apoio Pedagógico, Professor de Apoio Escolar - Higienizador, Professor de Atendimento Educacional Especializado, Intérprete de Libras, Instrutor de Libras e Instrutor de Braille) e elas puderam optar/escolher por quantos quisessem.

Nas escolas onde atuam as interlocutoras desta pesquisa foram identificados três tipos de profissionais de apoio: escolar higienizador, de AEE e pedagógico. De acordo com as Diretrizes Operacionais da Secretaria de Educação de Goiás ${ }^{2 \mathrm{I}}$, os profissionais apontados pelas docentes, tem entre suas principais funções:

O Profissional de Apoio Escolar - Higienizador deverá atender o estudante com deficiência que apresenta dificuldade ou limitação na locomoção, higienização pessoal e na alimentação, principalmente nos intervalos escolares, incluindo recreios e eventos extraclasse (GOIÁS, 2020, p. 134).

O Professor de Atendimento Educacional Especializado - AEE deverá “[...] subsidiar as atividades pedagógicas das unidades educacionais a partir de atividades de formação continuada, orientando os Professores Regentes no que se refere ao processo ensino aprendizagem dos estudantes com deficiências, transtornos globais do desenvolvimento, altas habilidades/superdotação; [...] atender aos estudantes, $[. .$.$] , atentando para o fato de que este atendimento não$

\footnotetext{
20 “[...] totalidade de ações, metas e planos que os governos (nacionais, estaduais ou municipais) traçam para alcançar o bem-estar da sociedade e o interesse público (SEBRAE, 2008, p. 5).

${ }^{21}$ Diretrizes estabelecidas para os anos de 2020 a 2022.
} 
deverá consistir em uma aula de reforço, mas na complementação e/ou suplementação dos conteúdos mediados na sala de aula comum” (GOIÁS, 2020, p. $131-132)$.

O Profissional de Apoio Pedagógico deverá “[...] atuar em sala de aula, atendendo os estudantes que possuem deficiência intelectual associado ou não a outro tipo de deficiência ou transtorno global do desenvolvimento. Além de colaborar pedagogicamente com o Professor Regente junto aos estudantes com limitações motoras, paralisia cerebral, deficiência visual, deficiência auditiva, bem como, altas habilidades/superdotação (GOIÁS, 2020, p. 134).

Percebe-se, a partir das atribuições elencadas acima, o quanto estes profissionais e todos os demais são importantes no processo de inclusão das crianças com NEE no contexto escolar regular. E ainda, o quanto a formação continuada destes profissionais se faz necessária, pois esta permite aos docentes/colaboradores ofertar um trabalho com mais qualidade, principalmente no que se refere a utilização das tecnologias assistivas e no conhecimento e suporte às especificidades dos alunos.

Corroborando, Imbernón (2010, p. 8I) destaca que "[...] o desenvolvimento de todos os educadores e colaboradores de uma instituição de ensino [...] melhoram a situação laboral, o conhecimento profissional, as habilidades e atitudes dos trabalhadores envolvidos com a educação".

Um questionamento feito às participantes foi saber como se desenvolve/operacionaliza o processo de inclusão (crianças com NEE) na escola onde atuam. As respostas foram diversificadas.

Associaram o processo de inclusão ao laudo médico entregue pela família na unidade escolar.

A família da criança precisa trazer um laudo para unidade CMEI (Maria Eduarda, Regente, 202I).

O processo de inclusão se desenvolve por meio de um estudo da criança, verificar os laudos médicos, para saber quais as suas qualidades e necessidades [...] (Maria Lúcia, Regente, 2021).

Essas respostas chamam atenção ao destacar que a inclusão na EI se dá inicialmente pelo diagnóstico médico, ou seja, sinalizam a necessidade de um parecer "especialista" para posteriormente direcionarem o trabalho a ser realizado com as crianças.

Neste sentido, Carvalho aponta (2009, p. 127):

O diagnóstico como prática que ainda é exercida com a finalidade de triagem do alunado, tem sido uma das mais sérias barreiras que temos enfrentado para a implementação da educação inclusiva. [...] É como se a classificação permitisse saber o melhor procedimento a ser utilizado para a remoção de barreiras, mas, na prática, tem funcionado como mais uma barreira - a provocada pelos estigmas.

Outras respondentes relacionaram o processo de inclusão ao apoio (Equipe Multiprofissional/SME, Família e Professor).

Contamos com o apoio da equipe Multiprofissionais da secretaria de educação do município e com o professor de apoio. Porém, somos carentes de 
recursos/materiais específicos a necessidade das crianças. Sendo assim, a professora busca recursos próprios para atender as crianças com mais eficiência (Maria Alice, Regente, 2021).

$\mathrm{Na}$ minha escola pelo que presenciei nos anos anteriores, os apoios são poucos e fazem rodízio, mas esses apoios não são pessoas qualificadas para a função (maioria são contratos, somente com o término do ensino médio, ou são estudantes de pedagogia que nunca trabalharam com inclusão). A equipe da secretária de educação vai uma vez no início de cada ano letivo fazer a triagem desses alunos, analisando eles pessoalmente e a família, e caso necessite fazendo encaminhamento. O grande problema é que essa triagem é limitada, não atendem todos os alunos que necessitam.

E depois dessa triagem eles somem, não aparecendo mais na escola. Abreviando, na minha escola esse processo de inclusão depende somente dos professores, conversando entre si, trocando experiências, fazendo pesquisas e cursos por fora, para amenizar essa distância dos alunos e melhorar cada dia seu aprendizado interagindo sempre com o outro. Quando temos o apoio da família, crescemos juntos (Maria Divina, Regente, 2021).

[...] as profissionais de apoio estão sempre em sala acompanhando a criança, e nós professores procuramos englobar da melhor forma possível as atividades para que atenda às necessidades educacionais especiais da criança. Quando não conseguimos pedimos ajuda a equipe da secretária da educação para que ela encontre uma melhor maneira para atender "tal" criança (Maria Elisa, Apoio, 2021).

$\mathrm{Na}$ minha escola temos tido o apoio de um ajudante que fica junto na sala com essa criança para auxiliar nas atividades do dia a dia na escola. Além de um apoio da secretaria com auxílio a tratamentos específicos para essas crianças (Maria Júlia, Regente, 202I).

As respostas destacadas representam que incluir não simboliza somente o acesso da criança à escola, mas que conta com uma rede de apoio que agrega vários profissionais e a família para promover a inclusão da criança com NEE. No entanto, mesmo contando com esta rede, faltam recursos/materiais para garantir o atendimento específico para cada criança.

Disseram também que o processo inclusivo está relacionado às necessidades da criança, ou seja, é a partir das especificidades de cada aluno que se operacionaliza o processo de inclusão, como destacou uma das professoras: "Visa garantir o acesso $e$ atendimento dos alunos com necessidades educacionais especiais. a adequação e organização dos materiais são adaptadas para melhor atendimento na especificidade de cada criança" (Maria Clarice, Apoio, 202I). Isso significa que a inclusão se dá pela adaptação dos materiais a particularidade de cada criança.

Uma relacionou o processo inclusivo com a formação de professores: "com cursos de formação e orientações para os professores" (Maria Luiza, Regente, 202I). Sem dúvida configurase como primordial, mas não se limita a formação, mas a outros elementos conforme destacado pelas outras interlocutoras.

Algumas associaram processo de inclusão à interação, o acolhimento, socialização com a turma e o respeito ao tempo da criança: 
É importante que o professor estimule a criança interagir participar de todos os processos trabalhados em sala mas respeitando o tempo e o desejo de participar do educando (Maria Clara, Regente, 2021).

Observando as suas necessidades e especificidades para planejar ações necessárias de acolhida da criança na instituição. bem como, planejar atividades adaptadas para seu desenvolvimento, mas contudo, a incluindo na turma. Contamos com o auxílio do apoio da agente de apoio (Maria Beatriz, Regente, 2021).

A princípio a criança é acolhida na sala de aula por todos, ela "recebe" um profissional de apoio (que as vezes demora chegar) e atendimentos na sala de inclusão (Maria Aparecida, Apoio, 2021).

A interlocutora Maria Clara deu ênfase a interação por meio da promoção do professor e do respeito ao tempo da criança, já as outras duas ressaltaram o cuidado no planejamento das atividades e os atendimentos na sala do AEE e apontaram a questão do acolhimento, incluindo-a na turma toda.

Nesta linha de pensamento, Vygotsky (1999, p. 56) reforça que o ato de aprender pode ser concebido "[...] como um fenômeno que se efetiva na interação com o outro. [...], a aprendizagem se concretiza por meio da internalização, a partir de um processo anterior, de troca, que possui uma dimensão coletiva, do eu com o outro [...]”.

Em se tratando do acolhimento, Staccioli (2013, p. 28) salienta que "[...] acolher uma criança é, também, acolher o mundo interno da criança, as suas expectativas, os seus planos, as suas hipóteses e as suas ilusões [...]”.

Percebe-se ainda, numa das falas, que o respeito ao tempo da criança é essencial. Neste sentido, Mantoan (20II, p. 62) assevera que "[...] para ensinar a turma toda, parte-se da certeza de que as crianças sempre sabem alguma coisa, de que todo educando pode aprender, mas no tempo e do jeito que lhes são próprios”.

As respostas destas três últimas docentes sinalizam que o processo inclusivo tem caminhado em consonância com os preceitos norteadores da educação inclusiva, onde o respeito, a acolhida e convivência/socialização são também elementos basilares.

Enfim, observam-se inúmeras interpretações de como se operacionaliza a inclusão na escola onde atuam.

Outra indagação feita na pesquisa foi saber se o programa da inclusão é suficiente para atender as necessidades da criança com NEE. Apenas uma participante mencionou que o programa é eficaz, mas com ressalvas:

O programa da inclusão tem sido eficaz, porém precisa levar em consideração entre a teoria e a prática no cotidiano escolar do professor, numa sala de aula, onde o professor tem de atender a diversidade, tanto em relação as dificuldades de aprendizagem, como a diversidade comportamental. Com base no programa a escola tem cumprido seu papel com estratégias que permitam a integração dos alunos de forma mais autônoma, objetivando uma escola de qualidade para todos (Maria Lúcia, Regente, 202I).

As demais enfatizaram a ineficiência do programa e elegeram como as principais falhas a ausência de: i) materiais/recursos pedagógicos; ii) infraestrutura física com acessibilidade; iii) políticas públicas; iv) formação continuada de professores; v) participação da família; vi) qualificação profissional dos apoios. Visto que se faz necessário acompanhar 
[...] o percurso de cada estudante, do ponto de vista da evolução de suas competências para resolver problemas de toda ordem, mobilizando e aplicando conteúdos acadêmicos e outros meios que possam ser úteis para se chegar a soluções pretendidas, apreciam-se seus progressos na organização dos estudos; no tratamento das informações e na participação na vida social da escola (MANTOAN, 20II, p. 63).

\section{Corroborando, Carvalho (2014, p. 98) enfatiza que:}

A inclusão no espaço escolar além das ações de ensino-aprendizagem circunscritas à escola, pressupõe mudanças em inúmeros aspectos, dentre os quais: a acessibilidade física e atitudinal; a melhoria da qualidade na formação dos professores (inicial e continuada); revisão do papel político-social da escola, particularmente no mundo "globalizado"; previsão e provisão de recursos humanos, físicos, materiais e financeiros; valorização do magistério; vontade política para reverter as condições materiais de funcionamento das escolas brasileiras; e uma rede de suporte ao professor, ao aluno e a seus familiares.

Partindo das observações docentes, é possível inferir que para que a educação inclusiva aconteça de fato, faz-se necessário, primordialmente, investir em políticas públicas (e efetivá-las), pois a partir delas, soluções para as demais falhas serão possivelmente contempladas.

Já em relação às implicações relacionadas a permanência do aluno com NEE na sala de aula regular, as interlocutoras em sua grande maioria concebem essa presença como um direito da criança, portanto, deve ser respeitado, como destacaram:

Incluir a criança com necessidade especial de forma democrática, respeitando seus direitos e deveres como cidadão (Maria Alice, Regente, 202I).

Implica em reconhecer que cada educando possui sua especificidade e que devemos promover a garantia dos direitos de cada um, considerando as diferenças (Maria Gláucia, Regente, 2021).

A permanência das crianças com necessidades especiais na sala é o início do caminho para a verdadeira inclusão. Elas fazem parte do todo, da sociedade, da comunidade, do grupo. Precisamos ter um olhar diferenciado para cada criança e não apenas para aquelas que apresentam alguma deficiência. Cada uma é um ser único. E, incluir é abrir caminhos e não limitá-los (Maria Helena, Regente, 202I).

São crianças que possuem necessidades educacionais específicas, mas que devem conviver concordo todos os demais, pois são crianças como todos os outros. Separar a criança de inclusão é um grande retrocesso (Maria Lazara, Regente, 2021).

Além disso, destacaram que a presença dessas crianças na sala regular ajuda na construção gradativa do respeito às diferenças, auxilia no processo de criação de vínculos entre alunos com NEE e os demais.

A permanência de crianças especiais não só na minha sala, mas em toda educação regular é de fundamental importância pois ao socializar as crianças percebem que mesmo com alguma coisa de especial somos todos igual. Além de trabalhar com o respeito, as desigualdades criando vínculos. Essa troca entre as crianças especiais, as demais e os professores promove a igualdade (Maria Júlia, Regente, 202I). 
Acredito que um dos maiores desenvolvimento de alunos com necessidades especiais acontecem na socialização deles no ambiente escolar. Esse acesso é um direito de todas as crianças, sem discriminação, creio que essa troca seja proveitosa de ambas as partes, que as crianças consideradas "normais" convivam com essas diferenças e aprendam a respeitá-las desde pequenas, sejam elas crianças ou adultas (Maria Aparecida, Apoio, 2021).

Uma professora registrou a dificuldade das famílias dos alunos regulares em aceitar a criança com NEE na mesma sala. Apesar de não ter detalhado sua resposta, esse feedback demonstra o preconceito escolar/social, não somente porque não aceitam, mas por valorizarem as diferenças.

Carvalho (2014, p. 33-34) afirma que:

[...] as pessoas em situação de deficiência são representadas no imaginário social por suas "marcas", tornando-se a parte pelo todo. Valoriza-se a deficiência e perde-se a Pessoa em sua dimensão de integralidade. Criam-se os preconceitos e os estereótipos que desencadeiam discriminações alicerçadas em juízos de valor, geralmente dicotômicos e que se inscrevem as pessoas nas categorias de boas ou más, de melhores ou piores, de contributivas ou dependentes e assim por diante.

Assim, ter uma criança com NEE em sala faz com que

[...] a professora da educação infantil tenha que repensar seu papel mais uma vez, agora no que se refere a aspectos que até pouco tempo atrás cabiam apenas ao professor da educação especial. Junto a isso, há o fato de que a instituição em si, em termos estruturais, também deve rever seus ambientes, materiais, condição de acesso e permanência desse alunado (SOUZA, 2019, capítulo 6).

Quando perguntadas acerca dos elementos que evidenciam a aprendizagem/desenvolvimento da criança com NEE, as respostas foram diversificadas. Várias interlocutoras deram ênfase ao fator interação/socialização, como destacou uma das respondentes abaixo:

A interação com o outro, por meio de atividades planejadas especificamente de acordo com a sua capacidade de compreensão. Através do lúdico, da música, da dança e outros, que estimulem as crianças aprenderem de forma dinâmica e criativa os conteúdos escolares (Maria Alice, Regente, 2021).

Além da interação/socialização, outras destacaram a linguagem/comunicação e autonomia como elementos que evidenciam o desenvolvimento da criança, conforme salientaram as interlocutoras:

$\mathrm{Na}$ minha jornada percebo que a criança começa a se socializar, conviver e interagir com as outras crianças e professores. desenvolve a linguagem, a comunicação, os aspectos físicos, cognitivos e motor. Adquire autonomia para se alimentar para se expressar. a família, às vezes, relata mudanças no comportamento da criança para melhor e se sentem muito felizes com os progressos. A criança começa a demonstrar as suas preferências, seus gostos como ouvir uma música, manusear uma massinha, brincar com um determinado brinquedo, ouvir a história, participar de um momento de música, adquirindo confiança e fazendo parte do seu processo de aprendizagem (Maria Beatriz, Regente, 202I). 
O desenvolvimento oral, a interação com outras crianças e sua autonomia (Maria Carolina, Regente, 202I).

Uma maior participação nas atividades cotidianas com autonomia (Maria Gláucia, Regente, 202I).

A interação da criança com os demais do grupo. A comunicação, a expressão, o reconhecimento... (Maria Helena, Regente, 2021).

Essas respostas sustentam que a educação faz a diferença, contribui não somente no processo cognitivo, mas no afetivo, na participação e autonomia da criança com NEE. Isso significa que:

Quando a instituição de Educação Infantil percebe que ela é um mundo no qual cabem muitos outros, e desenvolve uma membrana permeável e flexível possibilitando uma troca fecunda entre esses diferentes mundos, as crianças ganham qualidade no exercício do pensamento, buscam conhecer cada vez mais, estabelecer relações, procuram um sentido pessoal naquilo que aprendem e compartilham conhecimento com outras crianças e adultos (ORTIZ, 20II, p. 56).

Foi questionado também se o sistema educacional do município de Trindade/GO, incentiva a participação em cursos de formação continuada. A maioria das respondentes (24; 96\%) afirmaram que sim.

Neste contexto, foi buscado junto a SME a oferta dos cursos e a respectiva participação docente. No entanto, é oportuno destacar que durante o período de realização desta pesquisa, foi repassado que devido ao processo de contratação de novos profissionais, não haviam capacitações voltadas para Educação Inclusiva, mas que estas já estavam sendo planejadas.

Seguem algumas das formações (Workshops) ofertadas durante o Io semestre/202I, que teve como temática a "Tecnologia Educacional: ressignificando a educação por meio das ferramentas digitais", cujo objetivo principal foi possibilitar aos profissionais da educação, formação continuada sobre novas tecnologias e a utilização das ferramentas digitais, de modo a favorecer o processo de ensino-aprendizagem dos alunos.

a) Workshop I: Selfie em Vídeo - Tenho que gravar um vídeo para minhas aulas e agora?

Participantes: 294 docentes.

b) Workshop II: Formação de professores - Ensino Híbrido e Criativo - Como utilizar as plataformas virtuais de ensino e as ferramentas digitais. Participantes: 362 docentes.

c) Workshop III: Professores em REANP, e agora? Procedimentos e estratégias educacionais possíveis neste contexto.

Participantes: 35I docentes.

d) Workshop IV: Produção de aulas ao vivo e gravadas.

Participantes: 30I docentes.

e) Workshop V: Ferramentas do Gmail - Google Forms e seus principais usos. Participantes: 338 docentes.

f) Workshop VI: Conhecendo e Criando com o Canva e o Padlet.

Participantes: 260 docentes. 
Diante das capacitações apresentadas, percebe-se que existe uma preocupação por parte do Município em preparar seu corpo docente, tendo em vista que tais formações contemplam o ensino remoto ocasionado pelo atual cenário pandêmico do COVID-ig.

Corroborando, Imbernón (2010, p. 9) salienta que “[...] não podemos separar a formação do contexto do trabalho [...]. O contexto condicionará as práticas formadoras, bem como sua repercussão nos professores e sem dúvida, na inovação e na mudança".

Partindo dos apontamentos das interlocutoras desta pesquisa, denota-se que a escola e o professorado têm um desafio imenso pela frente na promoção da educação inclusiva, mesmo com limitações (recursos pedagógicos, de infraestrutura e de apoio), ineficiência de políticas públicas e outros fatores é preciso oportunizar as crianças com NEE e todas a demais, o acesso a uma educação de qualidade e gratuita.

De modo geral, este estudo mostrou que muito ainda precisa ser feito no âmbito da educação inclusiva no município de Trindade/GO. Revelou o quanto a formação continuada na área constitui um elemento basilar no processo de ensino e aprendizagem de crianças com NEE. Mas, por si só, não garante que a escola inclusiva de fato inclua.

É preciso investimento em recursos pedagógicos, pois cada criança com NEE tem necessidades particulares que precisam ser consideradas e respeitadas para que o processo de aprendizagem aconteça. Todavia, sabe-se que esta realidade não se limita ao município estudado:

A educação ainda não recebe financiamento suficiente. Muitos governos aumentaram o investimento, mas poucos priorizaram a educação em seus orçamentos nacionais, e a maioria não alocou os $20 \%$ recomendados para cobrir as lacunas do financiamento. $\mathrm{O}$ mesmo quadro se repete com os doadores que, após um impulso inicial nos orçamentos de ajuda, reduziram a verba destinada à educação desde 2010 e não priorizaram suficientemente os países mais necessitados (UNESCO, 2015, p. 3).

É necessário melhorar a infraestrutura das instituições, por constituir quesito básico para receber a criança com NEE, ou melhor, é preciso remover as diversas barreiras que impedem o ir e vir de todas as pessoas, incluindo os alunos com e sem necessidades educacionais específicas.

Outro elemento que agrega para legitimar a educação inclusiva é a qualidade formativa da equipe de apoio, pois incluir não se limita a acolher/cuidar/integrar, mas perpassa por habilidades e estratégias pedagógicas que só podem ser fomentadas pela formação continuada.

\section{CONSIDERAÇÕES FINAIS}

A discussão da temática - Educação Inclusiva - é de extrema importância. Assim, faz-se necessário refletir e saber como de fato a inclusão da criança com NEE acontece no contexto educacional. $O$ interesse em pesquisar o tema surgiu em virtude de algumas particularidades, entre elas a que se refere ao papel social da escola que legalmente deve oferecer um ensino inclusivo já nas séries iniciais. Partindo dessa premissa e com o intuito de inserção no campo do debate e reflexões sobre o assunto, a presente pesquisa se orientou 
a partir do seguinte questionamento: como acontece o processo da inclusão na Educação Infantil, sob o ponto de vista do professor?

De acordo com dados levantados foi possível elucidar como está acontecendo o processo inclusivo escolar das crianças no referido município. Tal cenário tem se configurado a partir de instituições favoráveis à inclusão, contando com diretores, coordenadores, colaboradores e docentes totalmente abertos a esta questão e cientes da importância da presença das crianças com NEE no contexto regular de ensino. E principalmente, reconhecendo como um direito garantido e que obrigatoriamente deve ser respeitado.

As instituições contam, na sua maioria, com profissionais de apoio (pedagógico e higienizador), além dos professores regentes. Tem-se ainda, professores do AEE, que segundo a SME atuam em oito salas de recursos multifuncionais. Tanto as famílias quanto a equipe de multiprofissionais desta Secretaria (assistente social, fonoaudióloga, psicóloga e psicopedagoga) são consideradas pelas docentes como auxiliares no atendimento às crianças que apresentam necessidades educacionais específicas.

O sistema educacional do município incentiva a participação docente em cursos de formação continuada ${ }^{22}$. No entanto, foi possível identificar a partir de algumas falas, que o despreparo de alguns profissionais compromete substancialmente a inclusão das crianças, pois contratam-se apoios sem qualificação. Relatos preocupam no sentido das crianças com NEE estarem sendo assistidas por cuidadores, ao invés de formadores. Esta falta de conhecimento em lidar com as especificidades dos discentes é um fator prejudicial, pois interfere no desenvolvimento. Todavia, a pesquisa destacou que um diferencial que perpassa o professorado participante é a referida capacitação, onde a grande maioria fez curso(s) de pós-graduação. Essa particularidade ajuda a lidar com a diversidade em sala de aula e a enxergar o que precisa e deve ser feito para a inclusão de fato acontecer. Além disso, possibilita a criação de estratégias interativas que favoreça o desenvolvimento cognitivo, afetivo e social, bem como contribui para o processo de ensino e aprendizagem.

Considerando a sinalização docente acerca do despreparo profissional, ressalta-se de maneira genérica e não apenas em relação as contratações temporárias, que este pode ser fruto de formações aligeiradas e superficiais, as quais não conseguem contemplar todos os conhecimentos necessários para a atuação na escola inclusiva. Percebe-se que a formação inicial não prepara para atender as especificidades dos alunos e por isso, os cursos de formação continuada devem ser uma constância no contexto de trabalho, pois capacitações devem partir também das dificuldades vivenciadas no ambiente educacional, ou seja, da prática em serviço.

\footnotetext{
${ }^{22}$ A presente pesquisa teve início no final da gestão municipal (2017/2020) com a tramitação dos documentos necessários para autorização do estudo e posterior aprovação pelo Comitê de Ética em Pesquisa. O processo investigativo, propriamente dito, começou na nova gestão (2021/2024), fator este contributivo para que muitos dos

questionamentos feitos à Secretaria Municipal de Educação (acerca da formação continuada dos professores) não fossem contemplados em função da ausência de dados relativos a gestão passada. Neste sentido, restaram inquietações/lacunas para futuros estudos, tendo em vista que a essência do trabalho docente perpassa por um contínuo processo de reflexão/capacitação.
} 
O estudo revelou que o trabalho desenvolvido pelas docentes é marcado pelo sentimento de pertença, não somente no acolhimento, mas ao planejarem as atividades propostas em sala de aula, promovendo a interação e considerando o que é particular a cada criança, mesmo desprovido de condições materiais para tal fim.

Enfatizaram também a ineficiência do programa da inclusão no atendimento as necessidades educacionais específicas das crianças, destacando como principais falhas: ausência de materiais e recursos pedagógicos, infraestrutura física com acessibilidade, políticas públicas, formação continuada de professores, entre outras.

Frente a esta constatação docente, Carvalho (2014, p. 98) assevera que:

\begin{abstract}
A inclusão no espaço escolar além das ações de ensino-aprendizagem circunscritas à escola, pressupõe mudanças em inúmeros aspectos, dentre os quais: a acessibilidade física e atitudinal; a melhoria da qualidade na formação dos professores (inicial e continuada); revisão do papel político-social da escola, particularmente no mundo "globalizado"; previsão e provisão de recursos humanos, físicos, materiais e financeiros; valorização do magistério; vontade política para reverter as condições materiais de funcionamento das escolas brasileiras; e uma rede de suporte ao professor, ao aluno e a seus familiares.
\end{abstract}

Percebe-se, a partir da realidade exposta, que a inclusão verdadeira é um caminhar contínuo e que precisa da participação de toda a sociedade para que ela realmente se efetive no contexto educacional. Reafirma-se que a Educação Inclusiva é um processo que tem se configurado a partir de avanços e conquistas, tanto por parte dos alunos, quanto por parte dos professores, da própria escola e principalmente, em termos normativos. No entanto, sua operacionalização ao longo do tempo perpassa por obstáculos ${ }^{23}$ e estes têm prejudicado a prática inclusiva no cotidiano escolar. Os docentes vêm tentando, na medida das suas possibilidades e conhecimentos, fazer o melhor, mas isso não é o bastante. Sugere-se então, um despertar dos cidadãos no sentido de lutar pelos seus direitos, com vistas a efetivação/construção de políticas públicas que direcionem, literalmente, recursos para este fim.

A perspectiva da educação inclusiva contempla a ruptura de paradigmas, o ressignificar do fazer pedagógico, o aprendizado contínuo, a aceitação e o respeito as diferenças, a autonomia, a valorização das pessoas, o reconhecimento do direito de todos a uma educação de qualidade, etc. Enfim, estes apontamentos orientam para a edificação de uma sociedade verdadeiramente mais justa, humana, de(para) todos.

Espera-se que este estudo possa despertar reflexões mais profundas sobre a inclusão das crianças com NEE na Educação Infantil, promovendo um ambiente dialógico e de compartilhamento de saberes entre os diversos profissionais da área, sejam eles professores, coordenadores, diretores e outros envolvidos, incluindo as famílias e a comunidade, a fim de buscarem juntos - a equidade educacional - caminho este que

23 tais como: ausência de recursos (financeiros, materiais e humanos), profissionais não habilitados, desvalorização do trabalho docente, infraestrutura física das escolas em situação precária, grande número de alunos em uma mesma sala e etc. 
certamente tornará as escolas do município de Trindade/GO cada vez mais inclusivas para todas as crianças.

Cabe ressaltar que o processo de pesquisa perpassa por uma contínua atividade crítica e reflexiva, o que permitiu identificar lacunas que impossibilitaram a apresentação de resultados precisos. No entanto, tem-se a consciência que, em nenhum momento, houve a pretensão de se encerrar o assunto, pelo contrário, ficará a expectativa de estimular outros pesquisadores a aprofundar nos estudos relacionados à temática. Salienta-se ainda que um "profundo sentimento" deixou marcas nesta pesquisadora ${ }^{24}$, tamanha vontade em observar e sentir mais de perto como é o cotidiano das crianças com NEE na Educação Infantil e dialogar com as suas respectivas docentes, haja visto que em função do cenário pandêmico (COVID-I9), não foi possível estar, presencialmente, nas unidades escolares do município de Trindade/GO.

\section{REFERÊNCIAS}

ALVES, Denise de Oliveira. Os desafios para a política e a pesquisa em Educação Especial no Brasil. In: MENDES, Enicéia Gonçalves; ALMEIDA, Maria Amélia; HAYASHI, Maria Cristina Piumbato Innocentini. (Orgs.). Temas em educação especial: conhecimentos para fundamentar a prática. Araraquara, SP: Junqueira \& Marin, 2008.

AMERICAN PSYCHIATRIC ASSOCIATION (APA). Manual diagnóstico e estatístico de transtornos mentais: DSM-IV. Tradução: Claudia Dornelles. 4. ed. Porto Alegre: Artmed, 2002.

ARAÚJO, Álvaro Cabral; NETO, Francisco Lotufo. A nova classificação americana para os transtornos mentais - o DSM-5. Revista Brasileira de Terapia Comportamental e Cognitiva, v. I6, n. I, p. 67-82, 2014. Disponível em: http://pepsic.bvsalud.org/pdf/rbtcc/vi6ni/vi6nia07.pdf. Acesso em i2 jun. 2021.

BARDIN, Laurence. Análise de conteúdo. Tradução: Luís Antero Reto; Augusto Pinheiro. São Paulo: Edições 7o, 2011.

BHERING, Eliana; DE NEZ, Tatiane Bombardelli. Envolvimento de pais em creche: possibilidades e dificuldades de parceria. Psicologia: Teoria e Pesquisa, Brasília, v. I8, n. I, p. 63-73, jan./abr. 2002. Disponível em: https://www.scielo.br/j/ptp/a/dnfKzsdknbC5Yttfq3 YQmXG/?lang=pt\&format=pdf.

Acesso em 03 jul. 2021.

BRASIL. Lei n. 9.394, de 20 de dezembro de 1996. Estabelece as diretrizes e bases da educação nacional. Disponível em: http://www.planalto.gov.br/ccivil_o3/leis/l9394.htm. Acesso em 02 fev. 2020.

\footnotetext{
${ }^{24}$ Sou pesquisadora iniciante na área da Educação.
} 
BRASIL. Decreto n. 3.298, de 20 de dezembro de 1999. Regulamenta a Lei n 7.853, de 24 de outubro de 1989, dispõe sobre a Política Nacional para a Integração da Pessoa Portadora de Deficiência, consolida as normas de proteção, e dá outras providências. Disponível em: http://www.planalto.gov.br/ccivil_03/decreto/d3298.htm. Acesso em I8 fev. 2020.

BRASIL. Ministério da Educação. Conselho Nacional de Educação. Parecer CNE/CP n. 9, de o8 de maio de 20or. Diretrizes Curriculares Nacionais para a Formação de Professores da Educação Básica, em nível superior, curso de licenciatura, de graduação plena. Disponível em:

http://portal.mec.gov.br/cne/arquivos/pdf/oo9.pdf. Acesso em o6 jul. 2020.

BRASIL. Ministério da Educação. Resolução CNE/CEB n. 2, de II de setembro de 200 . Institui Diretrizes Nacionais para a Educação Especial na Educação Básica. Secretaria de Educação Especial. MEC; SEESP, 200I. Disponível em: http://portal.mec.gov.br/cne/arquivos/pdf/CEBozor.pdf. Acesso em io abr. 2020.

BRASIL. Ministério da Educação. Secretaria de Educação Especial. Decreto n. 5.296, de 02 de dezembro de 2004. Regulamenta as Leis ns. 10.048, de 8 de novembro de 2000, que dá prioridade de atendimento às pessoas que especifica, e 10.098, de i9 de dezembro de 2000, que estabelece normas gerais e critérios básicos para a promoção da acessibilidade das pessoas portadoras de deficiência ou com mobilidade reduzida, e dá outras providências. Disponível em: http://www.planalto.gov.br/ccivil_03/_ato20042006/2004/decreto/d5296.htm. Acesso em o6 abr. 2020.

BRASIL. Ministério da Educação. Secretaria de Educação Especial. Decreto n. 5.626, de 22 de dezembro de 2005. Regulamenta a Lei n. 10.436, de 24 de abril de 2002, que dispõe sobre a Língua Brasileira de Sinais - Libras, e o art. I8 da Lei n. Io.098, de I9 de dezembro de 2000. Disponível em: http://www.planalto.gov.br/ccivil_03/_ato20042006/2005/decreto/d5626.htm.

Acesso em o6 abr. 2020.

BRASIL. Educação infantil: saberes e práticas da inclusão. Dificuldades acentuadas de aprendizagem: deficiência múltipla. Brasília: MEC/SEESP, 2006. Disponível em: http://portal.mec.gov.br/seesp/arquivos/pdf/deficienciamultipla.pdf. Acesso em: o8 fev. 2021.

BRASIL. Comitê de Ajudas Técnicas, Secretaria Especial dos Direitos Humanos da Presidência da República (CORDE/SEDH/PR), 2007. Disponível em: https://www.assistiva.com.br/Ata_VII_Reuni\%C3\%A3o_do_Comite_de_Ajudas_T\% ${ }_{3} \mathrm{C}_{3}$ Agcnicas.pdf. Acesso em 22 mar. 2021.

BRASIL. Ministério da Educação. Secretaria de Educação Especial. Política Nacional de Educação Especial na Perspectiva da Educação Inclusiva. Brasília: MEC/SEESP, 2008. Disponível em: http://portal.mec.gov.br/arquivos/pdf/politicaeducespecial.pdf. Acesso 
em 02 fev. 2020.

BRASIL. Ministério da Educação. Resolução CNE/CEB n. 4, de 02 de outubro de 2009. Institui Diretrizes Operacionais para o Atendimento Educacional Especializado na Educação Básica, modalidade Educação Especial. Disponível em: http://portal.mec.gov.br/dmdocuments/rceboo4_09.pdf. Acesso em 27 mar. 2020.

BRASIL. Lei n. 12.764, de 27 de dezembro de 2012. Institui a Política Nacional de Proteção dos Direitos da Pessoa com Transtorno do Espectro Autista e altera o $\S 3^{\circ}$ do art. 98 da Lei n. 8.II2, de II de dezembro de i99o. Disponível em: http://www.planalto.gov.br/ccivil_03/_ato2oII-2014/2012/lei/li2764.htm. Acesso em I7 jun. 2021.

BRITO, Lucinda Ferreira. Por uma gramática de língua de sinais. 2. ed. Rio de Janeiro: Tempo Brasileiro, 2010.

CARVALHO, Rosita Edler. Educação inclusiva: com os pingos nos "is". 9. ed. Porto Alegre: Mediação, 2009.

CARVALHO, Rosita Edler. Escola inclusiva: a reorganização do trabalho pedagógico. 6. ed. Porto Alegre: Mediação, 2014.

DRAGO, Rogério. Inclusão na educação infantil. 2. ed. Rio de Janeiro: Wak, 2014.

EMÍLIO, Solange Aparecida; CINTRA, Flávia Beillo Menaldo. Sobre abismos e pontes: entre a inclusão desejável e a possível. In: FRELLER, Cintia Coplt; FERRARI, Marian Ávila de Lima e Dias; SEKKEL, Marie Claire. (Orgs. ). Educação inclusiva: percursos na educação infantil - Laboratório de estudos sobre o preconceito - LAEP. São Paulo: Casa do Psicólogo, 20II.

FELIPE, Tanya Amara; MONTEIRO, Myrna Salerno. Libras em contexto. Curso básico: livro do professor. 6. ed. Brasília: MEC/SEESP, 2007.

FREIRE, Paulo. Pedagogia do oprimido. 17. ed. Rio de Janeiro: Paz e Terra, 1987.

FRÓES, Marco Antônio de Melo. A escolarização das pessoas com deficiência visual: contribuições e limites das atividades pedagógicas mediadas na sala de integração e recursos visual. I3I fls. Dissertação (Mestrado em Educação). Porto Alegre/RS: Universidade Federal do Rio Grande do Sul, 2015.

GIL, Antônio Carlos. Métodos e técnicas de pesquisa social. 5. ed. São Paulo: Atlas, I999.

GIL, Antônio Carlos. Como elaborar projetos de pesquisa. 4. ed. São Paulo: Atlas, 2002. GOIÁS. Secretaria de Estado da Educação. Diretrizes operacionais da rede pública 
estadual de educação de Goiás: 2020-2022. Goiânia: SEDUC/GO, 2020. Disponível em: https://site.educacao.go.gov.br/wp-

content/uploads/2020/o2/Diretrizes_Operacionais_Rede_Publica_Estadual_de_Educacao_d e_Goias_2020_2022.pdf. Acesso em o8 jul. 2021.

IBGE. Censo demográfico: resultados preliminares. Brasil, 20 оо.

IDE, Sahda Marta. O jogo e o fracasso escolar. In: KISHIMOTO, Tisuko Morchida. (Org.). Jogo, brinquedo, brincadeira e a educação. São Paulo: Cortez, 2008.

IMBERNÓN, Francisco. Formação continuada de professores. Tradução: Juliana dos Santos Padilha. Porto Alegre: Artmed, 2010.

JÚNIOR, Marcílio Barbosa Mendonça de Souza; MELO, Marcelo Soares Tavares de; SANTIAGO, Maria Eliete. A análise de conteúdo como forma de tratamento dos dados numa pesquisa qualitativa em educação física escolar. Movimento. Porto Alegre, v. i6, n. 3, p. 31-49, jul./set. 2010. Disponível em: https://seer.ufrgs.br/Movimento/article/viewFile/II546/10oo8. Acesso em io jun. 202I.

KNECHTEL, Maria do Rosário. Metodologia da pesquisa em educação: uma abordagem teórico-prática dialogada. Curitiba: Intersaberes, 2014.

MACHADO, Maria Lúcia de A. Educação Infantil e sócio-interacionismo. In:

OLIVEIRA, Zilma de Moraes Ramos de. (Org.). Educação infantil: muitos olhares. 6. ed. São Paulo, Cortez, 2004.

MANTOAN, Maria Teresa. Eglér. (Org). O desafio das diferenças nas escolas. 4. ed. Petrópolis, RJ: Vozes, 20II.

MANTOAN, Maria Teresa Eglér. Inclusão escolar: caminhos, descaminhos, desafios, perspectivas. In: MANTOAN, Maria Teresa Eglér. (Org). O desafio das diferenças nas escolas. 4. ed. Petrópolis, RJ: Vozes, 201 .

MANTOAN, Maria Teresa Eglér. Ensinando a turma toda: as diferenças na escola. In: MANTOAN, Maria Teresa. Eglér. (Org). O desafio das diferenças nas escolas. 4. ed. Petrópolis, RJ: Vozes, 20Ir.

MELO, Francisco Ricardo Lins Vieira de; FERREIRA, Caline Cristine de Araújo. O cuidar do aluno com deficiência física na educação infantil sob a ótica das professoras. Revista Brasileira de Educação Especial, Marília, v. I5, n. I, p.121-140, jan./abr. 2009. Disponível https://www.scielo.br/j/rbee/a/fDGBRWThcds3fgVdQXp3bDN/?lang=pt\&format=pdf . Acesso em 21 mai. 2021. 
MITTLER, Peter. Educação inclusiva: contextos sociais. Porto Alegre: Artmed, 2003.

MORET, Márcia Cristina Florêncio Fernandes; MENDONÇA, João Guilherme Rodrigues. A proposta bilíngue na educação de surdos: práticas pedagógicas no processo de alfabetização. Revista Produção e Desenvolvimento, v.2, n.3, p.14-2o, set./dez., 2016. Disponível em: https://revistas.cefetrj.br/index.php/producaoedesenvolvimento/article/view/er97/150.

Acesso em 23 out. 2021.

OLIVEIRA, Zilma de Moraes Ramos de. Educação infantil: fundamentos e métodos. 5. ed. São Paulo: Cortez, 2010.

ORTIZ, Cisele. Educação Infantil e exclusão cultural. In: FRELLER, Cintia Coplt; FERRARI, Marian Ávila de Lima e Dias; SEKKEL, Marie Claire. (Orgs.). Educação inclusiva: percursos na educação infantil - Laboratório de estudos sobre o preconceito LAEP. São Paulo: Casa do Psicólogo, 2orı.

PÉREZ, Susana Graciela Pérez Barrera; FREITAS, Soraia Napoleão. Encaminhamentos pedagógicos com alunos com altas habilidades/superdotação na educação básica: o cenário brasileiro. Educar em Revista, Curitiba, v. 27, n. 4I, p. I09-I24, jul./set. 20II. Disponível em: https://www.scielo.br/j/er/a/hv87 YLFWx6BGY 7 C8JCNqWjP/?lang=pt\&format=pdf. Acesso em ro jul. 2021.

PIRES, G. N. L. A criança e seu desenvolvimento emocional. Natal: SESC/RN, 2000.

PIRES, Edna Misseno. O estado do conhecimento sobre a educação de surdos: o discurso educacional brasileiro e o internacional. 165 fls. Tese (Doutorado em Educação). Goiânia/GO: Pontifícia Universidade Católica de Goiás, 2018.

PRIMO, Dorian Regina Batista Simões; JUNIOR, Ademar Simões da Motta. A influência da ludicidade na aquisição da aprendizagem de crianças com necessidades educativas especiais nas séries iniciais. In: CARVALHO, Edemir de; CARVALHO, Carmem Silvia B. F. (Orgs.). Práticas pedagógicas: entre as teorias e metodologias, as necessidades educativas especiais. São Paulo: Cultura Acadêmica, 2012.

QUADROS, Ronice Müller de; CAMPELlO, Ana Regina e Souza. A Constituição política, social e cultural da Língua Brasileira de Sinais. In: VIEIRA-MACHADO, Lucyenne Matos da

Costa; LOPES, Maura Corcini. (Orgs.). Educação de Surdos: Políticas, Língua de Sinais, Comunidade e Cultura Surda. Santa Cruz do Sul/RS: EDUNISC, 2 oro.

REZENDE, Euzilene Ferreira de. Inclusão na educação infantil: o olhar dos professores da rede municipal de Trindade/GO. 173 fls. Dissertação (Mestrado em Educação). Inhumas/GO: Faculdade de Inhumas, 2021. 
ROCHA, Maíra Gomes de Souza da; PAIVA, Carla de. O desenvolvimento das estruturas psicológicas superiores em alunos com deficiência múltipla: uma análise a partir do uso de recursos de tecnologia assistiva. In: PLETSCH, Márcia Denise; SOUZA, Flávia Faissal de. (Orgs.). Observatório de educação especial e inclusão escolar: balanço das pesquisas e das práticas na Baixada Fluminense. São Carlos: Marquezine \& Manzini ABPEE, 2015.

SANTOS, Daísy Cléia Oliveira dos. Potenciais dificuldades e facilidades na educação de alunos com deficiência intelectual. Educação e Pesquisa, São Paulo, v. 38, n. 04, p. 935-948, out./dez. 2012. Disponível em: https://www.scielo.br/j/ep/a/xFx3 $\mathrm{Cz}_{3} \mathrm{H}_{5} \mathrm{dP}_{9} \mathrm{kGhk}_{9} \mathrm{Vm}_{3} 8 \mathrm{y} /$ ?lang=pt\&format=pdf.

Acesso em or jun. 2021.

SARTORETTO, Mara Lúcia. Inclusão: da concepção à ação. In: MANTOAN, Maria Teresa Eglér. (Org.). O desafio das diferenças nas escolas. 4. ed. Petrópolis, RJ: Vozes, 2011.

SASSAKI, Romeu Kazumi. Construindo uma sociedade para todos. Rio de Janeiro: WVA, 1997.

SEBRAE. Políticas Públicas: conceitos e práticas. Belo Horizonte: Sebrae/MG, 2008.

SOUZA, Nelly Narciso de. Educação infantil na perspectiva da inclusão: reflexões para novas ações. Curitiba: CRV, 2019. E-Book (124 p.). ISBN 978-85-444-3156-6, DOI 10.24824/978854443156.6.

STACCIOLI, Gianfranco. Diário do acolhimento na escola da infância. Tradução: Fernanda Ortale \& Ilse Paschoal Moreira. Campinas/SP: Autores Associados, 2013.

STAINBACK, Susan; STAINBACK, William. Inclusão: um guia para educadores. Tradução: Magda França Lopes. Porto Alegre: Artmed, I999.

TARDIF, Maurice. Saberes docentes e formação profissional. 17. ed. Petropólis, RJ: Vozes, 2002.

TIBALLI, Elianda Figueiredo Arantes. A escola inclusiva no Brasil: questões para o debate. RCE - Revista Científica de Educação, Inhumas, v. I, n. I, p. 142-16o, dez. 2016. Disponível em: https://seer.facmais.edu.br/rc/index.php/RCE/article/view/I3/II. Acesso em 04 jul. 2021.

TRINDADE. Secretaria Municipal de Educação. Formação continuada - tecnologia educacional: ressignificando a educação por meio das ferramentas digitais (2021-2024). Trindade, GO: Secretaria Municipal de Educação, 202I. 
UNESCO. Declaração mundial sobre Educação para Todos. Declaração de Jomtien. Jomtien/Tailândia: Unesco, I99o.

UNESCO. Declaração de Salamanca: sobre princípios, políticas e práticas na área das necessidades educativas especiais. Salamanca/Espanha: Unesco, 1994.

UNESCO. Relatório de monitoramento global de EPT. Educação para todos, 2000-2015: progressos e desafios, 2015. Disponível em: http://www.nepedeees.ufscar.br/navegacaolateral/textos/232565por.pdf. Acesso em is mai. 2021.

VYGOTSKY, Lev Semenovich. Pensamento e linguagem. São Paulo: Martins Fontes, 1999. 